Jolanta Janek

\title{
ROLA SEKTORA PAŃSTWOWEGO W POWOJENNYM ROZWOJU WŁOCH ORAZ W OKRESIE BOOMU GOSPODARCZEGO W LATACH 50. I 60. XX WIEKU
}

\section{Rys historyczny}

Początki interwencjonizmu państwowego we Włoszech, w formule, jaka upowszechniła się w XX w., sięgają okresu bezpośrednio po wybuchu I wojny światowej. W grudniu 1914 r., w perspektywie nieuchronnego przystąpienia tego kraju do wojny, grupa czterech banków ${ }^{1}$ powołała tzw. Konsorcjum na rzecz Subwencji dla Przemysłu (Consorzio per Sovvenzioni su Valori Industriali, CSVI), którego zasadniczym celem było finansowe wspieranie produkcji wojennej wybranych branż włoskiego przemysłu, m.in. hutnictwa oraz przemysłu stoczniowego i maszynowego. Podstawową formą oferowanej pomocy, w sytuacji notorycznego niedoboru kapitału obrotowego na tamtejszym rynku, było kredytowanie zakupu surowców lub poszczególnych etapów produkcji. Formalnie CSVI było podmiotem niezależnym od władz, jednak z uwagi na organizacyjne i personalne związki z Bankiem Włoch (Banca d'Italia) $)^{2}$ konsorcjum realizowało de facto interesy gospodarcze państwa ${ }^{3}$.

Na początku lat 20., na skutek kryzysu gospodarczego, jaki nastąpił w Europie po zakończeniu działań wojennych, włoskie hutnictwo, dotąd zaangażowane prawie w całości w produkcję zbrojeniową, znalazło się w stanie zapaści finansowej zagrażającej całej gospodarce. Dla ratowania największego i kluczowego przedsiębiorstwa tej branży - spółki „Ansaldo” rząd, dekretem nr 233 z 4 marca 1922 r., powołał przy CSVI tzw. Autonomiczną Sekcję Specjalną (Sezonie Speciale Autonomia del Consorzio per Sovvenzioni su Valori Industrialni), której powierzył zadanie sanacji ww. spółki

\footnotetext{
1 Konsorcjum utworzyły: Cassa di Risparmio delle Province Lombarde, Istituto delle Opere Pie di S. Paolo, Monte dei Paschi di Siena oraz Gruppo di Casse di Risparmio.

2 Statut Konsorcjum przewidywał m.in., że jego przewodniczącym zostawał z urzędu aktualny dyrektor generalny Banku Włoch.

3 A. Biscaini, P. Gnes, A. Roselli, Origini e sviluppo del Consorzio per Sovvenzioni su Valori Industriali durante il Governatorato Stringher, Bancaria, Roma 1987, s. 154.
} 
i przywrócenia jej płynności finansowej. Działaniami naprawczymi objęto również banki będące największymi wierzycielami „Ansaldo”: Banca Italiana di Sconto, Banca Italiana di Credito e Valori oraz Società Finaziaria per l'Industria e Commercio. Na urzeczywistnienie tego celu oraz ratowanie innych ważnych dla gospodarki włoskiej firm zagrożonych upadkiem Autonomiczna Sekcja Specjalna CSVI otrzymała początkowo z Banku Włoch fundusz dotacyjny w wysokości 1 mld lirów (40 mln USD) ${ }^{4}$. W następnych latach był on kilkakrotnie zwiększany. W 1926 r. wszystkie aktywa i zadania Autonomicznej Sekcji Specjalnej przejął powołany w jej miejsce Instytut Likwidacyjny (Istituto di Liquidazioni) mający status samodzielnego podmiotu prawa publicznego $^{5}$. Do zakończenia swojej działalności w 1932 r. Instytut Likwidacyjny przeznaczył na cele statutowe ponad $7 \mathrm{mld}$ lirów (ok. $290 \mathrm{mln}$ USD) ${ }^{6}$.

Włochy bardzo dotkliwie odczuły wpływ światowego kryzysu gospodarczego z przełomu lat 20. i 30. XX w. Nałożyły się na to negatywne skutki przeprowadzonej przez władze faszystowskie w 1927 r., motywowanej głównie względami polityki wewnętrznej, rewaluacji lira w stosunku do amerykańskiego dolara ${ }^{7}$, która doprowadziła do długotrwałego obniżenia się konkurencyjności włoskich towarów na rynkach międzynarodowych oraz drastycznego spadku eksportu. W 1933 r. PKB Włoch był o 28\% niższy niż w ostatnim przedkryzysowym roku 1928. Produkcja przemysłowa w tym okresie spadła o 30\%, a rolna aż o 47\%. Eksport obniżył się o 39\% ${ }^{8}$. W najgorszej sytuacji finansowej znalazły się zakłady przemysłu metalurgicznego i maszynowego oraz duża część sektora bankowego, przede wszystkim banki komercyjno-inwestycyjne, w których kapitałach znaczące udziały miały przedsiębiorstwa przemysłowe.

Model funkcjonowania banków oparty na równoczesnej działalności komercyjnej i inwestycyjnej przy partycypacji kapitałowej przemysłu miał we Włoszech tradycję sięgającą końca XIX w. i spełniał generalnie istotną, pozytywną rolę we wspieraniu rozwoju gospodarczego kraju w sytuacji notorycznego niedoboru kapitału na tamtejszym rynku. Jednak w czasach recesji powiązania kapitałowe banków i przemysłu okazały się czynnikiem pogłębiającym kryzys. Dla ratowania swoich przemysłowych udziałowców banki były zmuszone do dodatkowego ich finansowania, a w wielu wypadkach do przejmowania nad nimi kontroli właścicielskiej, co z kolei zwiększało ryzyko ich własnego bankructwa.

\footnotetext{
4 Wg kursu z 1922 r. (1 USD/25 ITL).

5 B. Stringher, Memorie riguardanti la circolazione e il mercato monetario, Banca d'Italia, Roma 1925, s. $69-80$.

6 Wg kursu z 1926r. (1 USD/24 ITL).

7 Kurs lira wzrósł z 24 ITL/1 USD w 1926 r. do 12 ITL/1 USD w 1931 r.

8 ISTAT, Statistiche storiche dell'Italia, Roma 1976, s. 113, 182.
} 
W obliczu tych zagrożeń rząd Mussoliniego przystąpił w 1933 r. do gruntownej reorganizacji systemu bankowego. $Z$ jednej strony wprowadzono w trybie nadzwyczajnym, w drodze dekretu rządowego, zakaz łączenia działalności inwestycyjnej i komercyjnej oraz wzmocniono rolę kontrolną i regulacyjną Banku Włoch ${ }^{9}, \mathrm{z}$ drugiej - zdecydowano o przejęciu przez państwo, w drodze wykupu większościowych udziałów, kontroli nad trzema największymi we Włoszech, najbardziej zagrożonymi upadkiem bankami komercyjno-inwestycyjnymi: Banca Commerciale Italiana, Banco di Roma i Credito Italiano ${ }^{10}$ oraz o przeprowadzeniu alokacji pakietów akcji przedsiębiorstw przemysłowych znajdujących się dotychczas w ich posiadaniu. Kluczowa rola w przekształceniach własnościowych przypadła Instytutowi Rekonstrukcji Przemysłu (Istituto per la Ricostruzione Industriale, IRI) - podmiotowi zarządzającemu ze 100\% udziałem skarbu państwa, powołanemu dekretem rządu 24 stycznia 1933 r. $\mathrm{Na}$ jego czele stanął zaufany doradca ekonomiczny Mussoliniego, Alberto Beneduce ${ }^{11}$. Wkrótce po ukonstytuowaniu się IRI zaczął realizować w imieniu państwa uprawnienia właścicielskie wobec świeżo pozyskanych banków, przede wszystkim pod kątem ich dokapitalizowania i poprawy kondycji finansowej, ustabilizowania akcjonariatu oraz restrukturyzacji. Pod bezpośredni zarząd IRI przeszły też wszystkie firmy, w których banki te posiadały dotąd pakiety kontrolne akcji. W wyniku przeprowadzonej alokacji udziałów IRI został właścicielem 21,5\% całego kapitału akcyjnego we Włoszech, stając się de facto największym pracodawcą w kraju z ponad 100 tys. podległych pracowników. Nominalna wartość przejętych aktywów wyniosła 16,7 mld lirów (ok. 1,4 mld USD), co stanowiło 14,3\% ówczesnego PKB ${ }^{12}$. Wśród około 100 firm, których IRI stał się akcjonariuszem, w dużej części większościowym, znalazły się istotne z punktu widzenia gospodarki kraju przedsiębiorstwa przemysłu stoczniowego (Cantieri Riuniti dell'Adriatico), metalurgicznego (Ilva, Terni), maszynowego (Ansaldo), sektora energetycznego (Società Meridionale di Elettricità, SME) oraz obsługujące sieci telekomunikacyjne (Società Idroelettrica Piemontese, SIP). Zachowały one dotychczasowy status spółek prawa handlowego, a ich akcje były nadal notowane na giełdzie.

9 Ustawa sankcjonująca zmiany w systemie bankowym wprowadzone ww. dekretem została przyjęta przez parlament 12 marca $1936 \mathrm{r}$.

10 Państwo stało się właścicielem 94\% akcji Banca Commerciale Italiana i Banco di Roma oraz 78\% akcji Credito Italiano. G. Candeloro, Storia dell'Italia moderna. Il fascismo e le sue guerre, Feltrinelli Editore, Milano 1981, s. 278.

11 Alberto Beneduce (1877-1944) - ekonomista, absolwent Uniwersytetu w Neapolu, do połowy lat 20. XX w. związany z partią socjalistyczną, z ramienia której został w 1919r. deputowanym do parlamentu, w 1925 r. zrezygnował z działalności parlamentarnej, zbliżył się do partii faszystowskiej i został doradcą ekonomicznym Mussoliniego, w latach 1933-1939 był prezesem IRI.

12 M. Franzinelli, M. Magnani, Beneduce, il finanziere di Mussolini, Mondadori, Milano 2009, s. 229. 
Zgodnie z dekretem stanowiącym IRI był podmiotem tymczasowym o zdefiniowanym celu działania. Po reorganizacji i uzdrowieniu sytuacji finansowej przejętych banków i przedsiębiorstw miał stopniowo zbywać posiadane w nich udziały inwestorom prywatnym i zakończyć swoją działalność. W ramach IRI wyodrębniono dwa działy. Banki, które uznano za instytucje ważne dla interesu narodowego, znalazły się pod nadzorem tzw. sekcji finansowania (sezione finanziamenti), natomiast pozostałe podmioty podporządkowano tzw. sekcji przekształceń (sezione smobilizzi).

$\mathrm{Z}$ uwagi na dużą liczbę kontrolowanych przedsiębiorstw oraz ich zróżnicowanie pod względem rodzaju prowadzonej działalności gospodarczej struktura ta okazała się jednak nieefektywna. IRI przystąpił więc do tworzenia spółek finansowo-zarządzających, w których posiadał 100\% udziałów i na które cedował uprawnienia właścicielskie wobec firm zależnych o zbliżonym profilu produkcyjnym lub handlowym. Już w październiku 1933 r. został powołany pierwszy taki subholding pod nazwą STET SpA (Società Torinese per l'Esercizio Telefonico), który przejął udziały przedsiębiorstw z sektora telekomunikacyjnego ${ }^{13}$. W 1936 r. rozpoczęła działalność Finmare SpA (Società Marittima Finanziaria), spółka finansowa grupująca firmy świadczące usługi morskie ${ }^{14}$, a w 1937 r. Finsider SpA (Società Finanziaria Siderurgica), która przejęła zarządzanie przedsiębiorstwami z branży metalurgicznej ${ }^{15}$. Dla sfinansowania działalności nowo powoływanych podmiotów IRI wyemitował w latach 1935-1937 trzy transze dwudziestoletnich obligacji zamiennych na akcje o łącznej wartości 2,2 mld lirów (157 mln USD) ${ }^{16}$.

Zakładany pierwotnie scenariusz reprywatyzacyjny został zrealizowany tylko w niewielkim zakresie, a do największych transakcji należała sprzedaż w $1935 \mathrm{r}$. dwóch mało istotnych spółek energetycznych: Edison i Batogi za kwotę 1,4 mld lirów $(100 \mathrm{mln} \text { USD })^{17}$. Wdrażana przez władze faszystowskie polityka autarkii, militarne zaangażowanie Włoch w Etiopii od 1935 r. oraz rosnące napięcie polityczne w Europie powodowały, że reżim Mussoliniego wolał utrzymać w rękach państwa kontrolę nad strategicznymi dla kraju przedsiębiorstwami i sektorami gospodarki. W konsekwencji takiego stanowiska zaniechano dalszej reprywatyzacji, a IRI został formalnie przekształcony 24 czerwca 1937 r. w tzw. przedsiębiorstwo permanentne (ente permanente), któremu powierzono na stałe zarządzanie aktywami państwowymi w gospodarce. Decyzja o zmianie jego statusu de facto usankcjonowała dotąd epizodyczny,

\footnotetext{
13 STET SpA objęła akcje firm SIP, Stipel, Telve oraz Timo.

14 Finmare SpA posiadała pakiety kontrolne akcji Italia di Navigazione, Lloyd Triestino, Adriatica di Navigazione oraz Tirrenia di Navigazione.

15 Finsider SpA objęła akcje zakładów Ilva, Terni, Dalmine oraz Acciaierie di Cornigliano.

16 G. Candeloro, op.cit., s. 281.

17 Ibidem, s. 280.
} 
wymuszony sytuacją kryzysową mariaż kapitału publicznego i prywatnego w spółkach kontrolowanych przez Instytut. Zyskał on charakter systemowy i w następnych latach stał się trwałym, znaczącym i charakterystycznym elementem gospodarki włoskiej.

IRI uzyskał prawo akwizycji na rynku kapitałowym kolejnych firm oraz otrzymał do dyspozycji pokaźny fundusz dotacyjny przeznaczony na dokapitalizowywanie spółek zależnych w sytuacjach nadzwyczajnych. Jednak głównym źródłem finansowania Instytutu miały być nadal emisje wieloletnich obligacji gwarantowanych przez państwo.

Rynkowy modus operandi Instytutu w działalności gospodarczej i w zarządzaniu podmiotami zależnymi w powiązaniu z modelem własności opartym na mieszanym, publiczno-prywatnym akcjonariacie znacząco odbiegał od sposobu zarządzania tradycyjnymi firmami państwowymi. Wśród ekonomistów zyskał z czasem miano formuły IRI. Przez zwolenników interwencjonizmu państwowego był uznawany za wariant alternatywny wobec klasycznej nacjonalizacji.

W 1937 r. IRI zatrudniał już 201 tys. pracowników i kontrolował 42\% włoskiego kapitału akcyjnego, w tym $100 \% \mathrm{w}$ przemyśle metalurgicznym produkującym na potrzeby armii oraz po $80 \% \mathrm{w}$ sektorze bankowym i w przemyśle stoczniowym ${ }^{18}$.

\section{Rysunek 1. Udziały IRI w wybranych gałęziach włoskiego przemysłu w 1937 r. (w \%)}

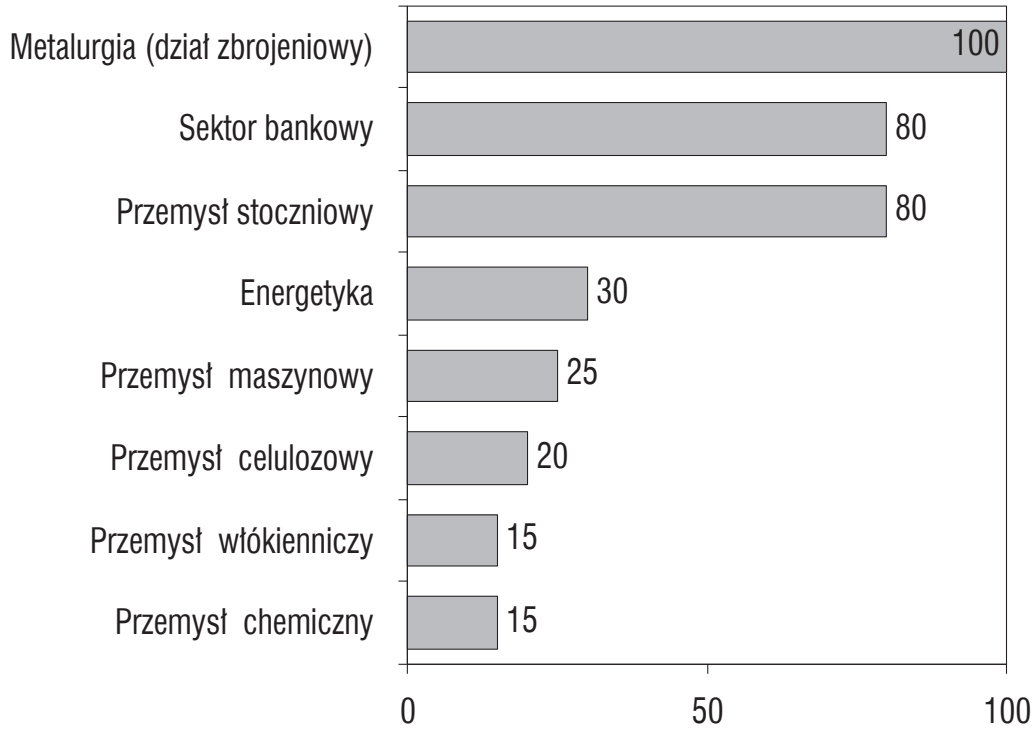

Źródło: Oprac. własne na podstawie: P. Bianchi, La rincorsa frenata. L'industria italiana dall'unità nationale All'unificazione europea, Il Mulino, Bologna 2002, s. 61-89.

${ }^{18} \mathrm{P}$. Bianchi, La rincorsa frenata. L'industria italiana dall'unita nazionale all'unificazione europea, Il Mulino, Bologna 2002, s. 61-89. 
W okresie II wojny światowej, a zwłaszcza w latach 1940-1943, kiedy zaangażowanie Włoch w działania wojenne było największe, samodzielność Instytutu w zakresie kształtowania własnej strategii gospodarczej została znacząco ograniczona, a gros jego potencjału produkcyjnego zostało podporządkowane celom zbrojeniowym. Udział IRI oraz pozostałej części sektora publicznego w PKB sięgnął wówczas 14,5\%, podczas gdy w 1937 r. wskaźnik ten wynosił 12\%, a w 1929 r. - 6,1\% ${ }^{19}$.

Po upadku rządu Mussoliniego w 1943 r. przyszłość Instytutu stanęła pod znakiem zapytania. Jego likwidacji, m.in. ze względu na bliskie związki kierownictwa z reżimem i ścisłe podporządkowanie działalności Instytutu polityce gospodarczej partii faszystowskiej, domagała się część ugrupowań koalicji antyfaszystowskiej, głównie środowiska liberalne. Decydujące okazało się jednak stanowisko Sojuszniczej Komisji Kontroli administrującej Włochami do połowy 1945 r., która opowiedziała się za utrzymaniem IRI i wykorzystaniem jego potencjału i zasobów do powojennej odbudowy kraju, przeprowadzenia demilitaryzacji gospodarki oraz niezbędnych zmian strukturalnych. Decyzję tę podtrzymało w 1946 r. Zgromadzenie Konstytucyjne głosami Chrześcijańskiej Demokracji, Włoskiej Partii Socjalistycznej oraz Włoskiej Partii Komunistycznej, aczkolwiek zbieżność stanowisk tych ugrupowań wynikała z odmiennych przesłanek programowych i doktrynalnych. Lewica widziała w działalności IRI możliwość dalszego wzmocnienia roli państwa w gospodarce, czego zawsze się domagała, natomiast w chadecji silną pozycję zdobywał nurt postulujący łączenie w polityce gospodarczej elementów doktryny społecznej Kościoła z doświadczeniami interwencjonizmu państwowego z okresu międzywojennego. W konsekwencji Instytut utrzymał swój status głównego administratora własności państwowej oraz zachował przedwojenne prerogatywy, m.in. prawo do akwizycji nowych spółek oraz emisji akcji i obligacji. Co więcej, uzyskał polityczne „błogosławieństwo” ze strony najsilniejszych ugrupowań politycznych na włoskiej scenie politycznej, co w późniejszych latach zaowocowało wzmocnieniem pozycji samego Instytutu i jego kierownictwa.

W pierwszych latach powojennych działalność IRI została podporządkowana zadaniu przestawienia produkcji zbrojeniowej kontrolowanych przez holding przedsiębiorstw na produkcję cywilną. Wymóg ten wynikał z postanowień traktatu pokojowego zawartego w lutym 1947 r. w Paryżu między władzami włoskimi i aliantami, który nakładał na Włochy, jako państwo pokonane, limity w zakresie liczebności sił zbrojnych oraz ograniczenia ilościowe w produkcji zbrojeniowej.

19 ISTAT, Statistiche storiche dell'Italia, op.cit., s. 182. 


\section{Powojenne uwarunkowania polityczne i ekonomiczne}

Włochy wyszły z II wojny światowej w stanie głębokiego kryzysu społeczno-ekonomicznego, którego skutki odczuwane były aż do $1948 \mathrm{r}$. W tym okresie w gospodarce dominowały negatywne zjawiska, które obserwowano już w ostatniej fazie działań wojennych: galopująca inflacja, niedostatek żywności, czarny rynek, niski poziom produkcji rolnej i przemysłowej, szybki wzrost bezrobocia. W dużej mierze do natężenia kryzysu przyczyniały się konflikty ideologiczne i niestabilność polityczna w łonie rządzącej koalicji chadecko-lewicowej oraz brak jakiejkolwiek spójnej polityki ekonomicznej pierwszych powojennych rządów koalicyjnych. Wobec sprzeczności programowych tworzących je partii kolejne, szybko zmieniające się gabinety nie były w stanie wypracować skutecznej strategii rozwojowej, stosowały więc wygodną filozofię pozostawienia gospodarki samej sobie, zakładając jej samoistne uzdrowienie ${ }^{20}$.

Najważniejszą barierę rozwojową gospodarki, a zwłaszcza przemysłu uzależnionego w znacznym stopniu od importu paliw stanowił permanentny niedostatek na rynku podstawowych surowców energetycznych, przede wszystkim węgla kamiennego, którego niedobór w tym czasie sięgał 55\%. Niewystarczająca była również podaż energii elektrycznej, której produkcja w porównaniu z 1938 r. była niższa o blisko $20 \%^{21}$. Poważnym problemem dla wielu przedsiębiorstw, w sytuacji faktycznego załamania się włoskiego systemu finansowego, było też utrzymanie na bezpiecznym poziomie płynności finansowej. W konsekwencji wiele zakładów albo ograniczało produkcję, albo w ogóle jej nie podejmowało.

Utworzenie przez Chrześcijańską Demokrację po wyborach parlamentarnych w 1948 r. alternatywnego układu rządowego z udziałem partii liberalnych, na którego czele stanął chadecki polityk Alcide De Gasperi ${ }^{22}$, zaowocowało ustabilizowaniem się sytuacji wewnętrznej i przede wszystkim wdrożeniem surowego programu sanacji gospodarki autorstwa liberalnego ekonomisty, ówczesnego wicepremiera oraz ministra skarbu i finansów Luigiego Einaudiego ${ }^{23}$. Odszedł on od filozofii poprzednich rządów uznających wzrost produkcji za jedyny zasadniczy warunek

${ }^{20}$ E. Możejko, Włochy a integracja zachodnioeuropejska, PISM, Warszawa 1972, s. 21.

${ }^{21}$ G. Podbielski, Italy: Development and Crisis in the Post-War Economy, University Press, Oxford 1974, s. 12.

22 Alcide De Gasperi (1881-1954) - dziennikarz, filozof blisko związany z Kościołem. Jeden z założycieli Włoskiej Partii Ludowej (1919 r.) i deputowany tej partii do parlamentu. W okresie dyktatury Mussoliniego więziony.

${ }^{23}$ Luigi Einaudi (1874-1961) - liberalny ekonomista, intelektualista, zwolennik monarchii. Senator (1919 r.), gubernator Banca d'Italia (1945-1948), w latach 1948-1955 prezydent republiki. 
rozwoju kraju, postawił na redukcję deficytu w obrotach handlowych, stabilizację monetarną i uzdrowienie finansów publicznych ${ }^{24}$. Stopniowo doprowadził do podniesienia podatków, zamrożenia płac, zdławienia inflacji oraz ustabilizowania cen, zaostrzenia kryteriów przyznawania firmom kredytów bankowych i znacznego wzrostu kosztów ich zaciągania. Jednak ograniczenia kredytowe stosowane wobec firm, obliczone głównie na eliminowanie mechanizmu finansowania za pośrednictwem kredytu bankowego spekulacyjnych zapasów tworzonych przez przemysł i handel, zaszkodziły działalności produkcyjnej, przede wszystkim mniejszych przedsiębiorstw niemających zdolności do samofinansowania. Mniej boleśnie niż cała gospodarka skutki restrykcji odczuł sektor państwowy. Przedsiębiorstwa podporządkowane IRI miały ułatwiony dostęp do kredytów bankowych i w odróżnieniu od firm prywatnych mogły korzystać z gwarancji rządowych, niejednokrotnie wykorzystywały też poparcie polityków dla pozyskiwania trudno dostępnych na wolnym rynku surowców i materiałów z importu.

Ceną, jaką gospodarka włoska zapłaciła za realizowanie kursu Einaudiego, było obniżenie dochodów pracowniczych, utrzymywanie się wysokiego bezrobocia i czasowy spadek produkcji przemysłowej sięgający wiosną 1948 r. 15\% w porównaniu z poziomem z października $1947 \mathrm{r}^{25}$ Jego niewątpliwą zasługą, poza zahamowaniem inflacji i przywróceniem zaufania społeczeństwa do narodowej waluty - lira, było stworzenie przesłanek makroekonomicznych do otwarcia się zamkniętej dotychczas gospodarki włoskiej na międzynarodową wymianę handlową.

Z krótkotrwałej zapaści przemysł wyszedł już we wrześniu 1948 r. Nastąpiła też wyraźna poprawa wyników eksportu, który w porównaniu z rokiem poprzednim wzrósł skokowo o 48\% (do $936 \mathrm{mln}$ USD). Przy stabilnym poziomie importu znacznie złagodziło to negatywny bilans obrotów bieżących. Na poprawę sytuacji w eksporcie złożyły się przede wszystkim konsekwentna polityka kursowa rządu skłaniająca przedsiębiorców do szukania rynków zbytu za granicą oraz spadek kosztów produkcji skutkujący obniżką cen eksportowych. Odnotowane wówczas ożywienie koniunktury dało początek trwałemu trendowi wzrostowemu w gospodarce.

Równocześnie z wprowadzaniem w życie programu sanacji gospodarki gabinet De Gasperiego rozpoczął realizację strategii przyspieszonej industrializacji. Ważnym czynnikiem ułatwiającym wdrażanie tej polityki było przystąpienie Włoch do finansowanego przez USA Europejskiego Programu Odbudowy (European Recovery Program), potocznie określanego jako plan Marshalla. W kolejnych latach programu

${ }^{24}$ E. Caruso, Storia ed economia italiane negli anni '50 e avvio anni '60, www.impresaoggi.com/articoli/, s. 11.

${ }_{25}$ W. Trznadel, Przestrzenne dysproporcje gospodarczo-społeczne we Włoszech XIX i XX wieku i drogi ich przezwyciężania, Wydawnictwo UWr, Wrocław 1988, s. 97. 
trwającego od kwietnia 1948 r. do połowy 1951 r. Rzym otrzymał amerykańską pomoc o wartości blisko 1,3 mld USD (11\% całości funduszy), co stanowiło 2,2\% ówczesnego PKB Włoch ${ }^{26}$. W pierwszej fazie, do połowy 1949 r. były to przede wszystkim dostawy surowców: węgla, bawełny, produktów naftowych. W drugim etapie Amerykanie poza surowcami zaczęli dostarczać także maszyny i wyposażenie dla przemysłu ${ }^{27}$. Otrzymane towary państwo sprzedawało odbiorcom prywatnym za gotówkę lub na kredyt, a uzyskane kwoty zasilały tzw. fundusz lirowy, który miał służyć do finansowania inwestycji publicznych. Wbrew założeniom programu, który przewidywał wykorzystanie funduszy pomocowych przede wszystkim do zainicjowania procesów przekształceń strukturalnych w gospodarkach poszczególnych krajów, Włochy przeznaczyły dużą część uzyskanych środków na zakup artykułów pierwszej potrzeby i towarów rynkowych, głównie w celu łagodzenia napięć społecznych powodowanych trudnymi warunkami życia ${ }^{28}$. Część kwot rząd wykorzystał ponadto w 1948 r. do zbilansowania budżetu oraz przeznaczył na uruchomienie w 1949 r. programu budowy tanich mieszkań komunalnych i społecznych. Reszta środków trafiła do przedsiębiorstw przemysłowych w formie kredytów i pożyczek na import maszyn i urządzeń. Do końca 1951 r. udzielono 1418 takich kredytów na sumę 376 mln USD ${ }^{29}$.

Pomoc w ramach planu Marshalla stworzyła wielu przedsiębiorstwom podstawy do modernizacji aparatu produkcyjnego i unowocześnienia procesów technologicznych. W dużej części beneficjentami programu były firmy państwowe $\mathrm{z}$ branży maszynowej i hutniczej zarządzane przez IRI.

\section{Rola sektora państwowego w okresie transformacji gospodarki (1948-1954)}

Rządowa strategia przyspieszonej industrializacji nadawała priorytet hutnictwu oraz przemysłowi ciężkiemu i maszynowemu, jako branżom uznawanym za kluczowe dla rozwoju całego przemysłu, oraz wyznaczała wiodącą rolę w realizacji tej polityki koncernowi IRI, którego pozycja i obecność kapitałowa w tych działach była dominująca.

Bezpośrednio po wojnie aktywność sektora państwowego w przemyśle stanowiła w pewnej mierze uzupełnienie działalności sektora prywatnego i koncentrowała

${ }^{26}$ G. Balcet, L'economia italiana, evoluzione, problemi e paradossi, Feltrinelli, Roma 1997, s. 49.

${ }^{27}$ K. Piotrowska-Hochfeld, Zagadnienia wzrostu gospodarczego Włoch, PWE, Warszawa 1964, s. 19.

${ }^{28}$ E. Możejko, op.cit., s. 24.

${ }^{29}$ K. Piotrowska-Hochfeld, op.cit., s. 19. 
się na dziedzinach i przedsięwzięciach charakteryzujących się wysokimi nakładami inwestycyjnymi, niską rentownością i często wysokim ryzykiem rynkowym, którymi kapitał prywatny nie był zainteresowany. Jednak z czasem, w okresie transformacji gospodarki znaczenie przedsiębiorstw kontrolowanych przez IRI zaczęło rosnąć, m.in. z uwagi na sprzyjający im klimat polityczny, bowiem za silną obecnością państwa w gospodarce opowiadała się większość włoskiej klasy politycznej zarówno o rodowodzie lewicowym, jak i chadeckim oraz centrowym.

Ponadto, w porównaniu z firmami prywatnymi, przedsiębiorstwa IRI miały ułatwiony dostęp do kapitału, korzystały z gwarancji rządowych oraz coraz częściej rozszerzały i dywersyfikowały swoją aktywność gospodarczą i podejmowały z sukcesem inicjatywy inwestycyjne w dziedzinach wykraczających poza dotychczasowy obszar działalności. W ich zainteresowaniu znalazły się m.in. branże o dużym potencjale rozwojowym, jak przemysł chemiczny, motoryzacyjny i AGD, usługi telekomunikacyjne, transport lotniczy, budowa autostrad i budownictwo przemysłowe.

W latach 1948-1954 sektor państwowy uczestniczył w kilku kluczowych dla gospodarki włoskiej przedsięwzięciach. Najważniejszym z nich była sanacja hutnictwa. Rząd prognozując szybki wzrost popytu na stal ze strony przemysłu ciężkiego i maszynowego oraz na potrzeby powojennej odbudowy kraju, przyjął w 1948 r. plan rekonstrukcji i rozwoju znajdującej się w zapaści branży hutniczej, tzw. plan Sinigaglia $^{30}$, który zakładał m.in. odbudowę zniszczonej w czasie wojny huty w Cornigliano, restrukturyzację zakładów w Piombino i Bagnoli oraz modernizację ich apartu wytwórczego i stosowanych procesów produkcyjnych, co w efekcie miało przynieść w perspektywie 4-5 lat wyraźne obniżenie kosztów działalności i odczuwalny wzrost produkcji stali, gwarantujący uniezależnienie się od jej importu. Realizację planu powierzono należącej do IRI grupie kapitałowej Finsider SpA zarządzającej udziałami państwa w sektorze hutniczym. Otrzymała ona na ten cel kwotę w wysokości 15 mld lirów w całości pochodzącą z kredytu uzyskanego w ramach planu Marshalla ${ }^{31}$.

Dzięki tak dużemu zastrzykowi środków finansowych hutnictwo zdołało bardzo szybko pokonać trudności z końca lat 40. i niemal podwoiło swoją produkcję stali z 2,2 mln t w 1948 r. do 4,2 mln w 1954 r. ${ }^{32}$ Jednocześnie nastąpił dynamiczny proces koncentracji i modernizacji produkcji. Efektem tego było z jednej strony ograniczenie zatrudnienia o blisko 8 tys. osób, z drugiej - wzrost wydajności oraz spadek kosztów wytwarzania.

30 Autorem planu był Oscar Sinigaglia (1877-1953) - inżynier, przedsiębiorca, w latach 1945-1953 prezes koncernu Finsider SpA.

31 F. Barca, Storia del capitalismo Italiano, Donzelli Editore, Roma 1997, s. 205-205.

32 ISTAT, Statistiche storiche dell'Italia, op.cit., s. 90-100; ISTAT, Annuario statistico 1955, Roma 1955, s. $180-191$. 
Równolegle IRI realizował, częściowo przy wykorzystaniu środków dostępnych w planie Marshalla, program restrukturyzacji i konsolidacji kontrolowanych przez siebie zakładów przemysłu maszynowego oraz unowocześnienia ich aparatu produkcyjnego. Do sfinansowania tych przedsięwzięć został stworzony pod koniec 1947 r. tzw. Fundusz na rzecz subwencjonowania przemysłu maszynowego (Fondo per la sovvenzione dell'industria meccanica, FIM) ${ }^{33}$, o kapitale 6 mld lirów, którego środki pochodziły w większości $z$ dotacji państwowych i emisji obligacji zamiennych na akcje ${ }^{34}$. Do zarządzania programem powołano w marcu $1948 \mathrm{r}$. nowy subholding branżowy IRI pn. Finmeccanica SpA (Società Finanziaria Meccanica), który stał się czwartą autonomiczną, obok Finmare SpA, Finsider SpA i STET SpA, grupą kapitałową Instytutu. Trzon nowo powstałej struktury stanowiły przedwojenne państwowe zakłady zbrojeniowe, które w wyniku procesu konwersji rozpoczętej w 1946 r. zmieniły profil produkcji na cywilny ${ }^{35}$.

Na początku lat 50 . Włochy przystąpiły do przemysłowej eksploatacji własnych, bogatych i łatwo dostępnych, a tym samym tanich złóż gazu ziemnego w Dolinie Padu. Miało to niezwykle istotne znaczenie dla włoskiej gospodarki. Z jednej strony pozwalało na znaczne ograniczenie importu paliw stanowiących ważną pozycję w bilansie handlowym i zwiększało poziom niezależności energetycznej kraju, z drugiej - stwarzało korzystne warunki do powstania i rozwoju nowoczesnego przemysłu chemicznego. Wydobycie padańskiego gazu podjął na zasadzie wyłączności państwowy Narodowy Koncern Naftowy (Ente Nazionale Idrocarburi, ENI) specjalnie powołany do tego celu w $1953 \mathrm{r}$. na bazie przedwojennego państwowego przedsiębiorstwa naftowego Agip (Azienda Generale Italiana del Petrolio). ENI otrzymał status instytucji przemysłowo-finansowej o charakterze użyteczności publicznej, której statutowym celem było koordynowanie działań państwa w zakresie poszukiwań i wydobycia paliw i surowców energetycznych. Z czasem zyskał pozycję monopolisty na rynku włoskim nie tylko w dziedzinie poszukiwań i wydobycia gazu oraz ropy naftowej, ale także w zakresie produkcji i transportu produktów naftowych ${ }^{36}$. W ciągu dwóch lat działalności ENI wydobycie gazu wzrosło czterokrotnie i w 1954 r. wyniosło $3 \mathrm{mld} \mathrm{m}^{3}$, całkowicie pokrywając zapotrzebowanie krajowej energetyki i przemysłu na ten surowiec ${ }^{37}$.

\footnotetext{
${ }^{33}$ FIM został powołany dekretem nr 889 prezydenta republiki z dnia 8 września $1947 \mathrm{r}$.

${ }^{34}$ F. Amatori, A. Colli, Impresa e industria in Italia dall'Unità a oggi, Marsilio, Venezia 2001, s. 320.

${ }^{35}$ W skład Finmeccanica SpA weszły m.in.spółki: OTO, Alfa Romeo, Arsenale Triestino, Navalmeccanica, Stabilimenti Meccanici di Pozzuoli, San Giorgio, Motomeccanica i Industria Meccanica Napoletana.

${ }^{36}$ K. Piotrowska-Hochfeld, op.cit., s. 18-28.

37 ISTAT, Statistiche storiche dell'Italia, op.cit., s. 90-100; ISTAT, Annuario statistico 1955, op.cit., s. $180-191$.
} 
W połowie lat 50., a zwłaszcza po reformie statutu IRI w 1954 r., która zwiększała autonomię holdingu w zakresie kształtowania własnej strategii rynkowej, rozszerzała zakres jego działalności inwestycyjnej oraz zwiększała uprawnienia jego menedżmentu, sektor państwowy stał się głównym i zarazem uprzywilejowanym podmiotem na rynku włoskim. Bezpośrednio lub pośrednio kontrolował wówczas m.in. $100 \%$ wydobycia gazu i węgla, $90 \%$ produkcji surówki żelaza i $40 \%$ produkcji samochodów ${ }^{38}$.

Rysunek 2. Udziały sektora państwowego w wybranych gałęziach przemysłu w $1954 \mathrm{r}$. (w \%)

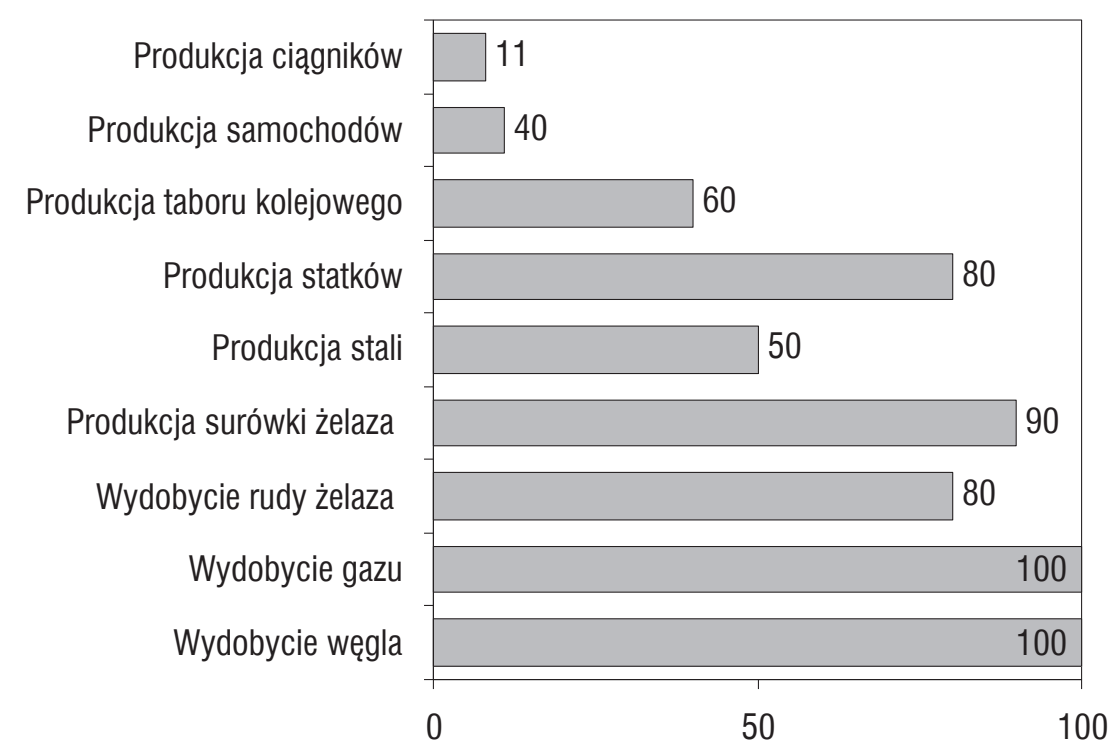

Źródło: Oprac. własne na podstawie: G. Maione, Spesa pubblica o consumi privati?, „Italia Contemporanea” 2003, nr 231, s. 13.

\section{Planowanie gospodarcze - „Dziesięcioletni plan rozwoju dochodów i zatrudnienia we Włoszech na lata 1955-1964"}

Rok 1954 stał się ważną cezurą w historii włoskiej polityki i rządzącej Chrześcijańskiej Demokracji (DC). Na kongresie partii w Neapolu nastąpiła radykalna zmiana pokoleniowa w jej władzach. Odeszli przedwojenni działacze, w tym dotychczasowy charyzmatyczny lider, pięciokrotny premier Alcide De Gasperi. Ich miejsce zajęli młodzi działacze ukształtowani politycznie po wojnie. Spośród ośmiu głównych, zachowujących dużą autonomię frakcji (correnti) zdecydowane zwycięstwo

38 G. Maione, Spesa pubblica o consumi privati?, „Italia Contemporanea” 2003, nr 231, s. 13. 
na kongresie odniosła tzw. Iniziativa democratica (Inicjatywa Demokratyczna) występująca z postulatami rewitalizacji oraz wzmocnienia organizacji i skuteczności partii ${ }^{39}$. Sekretarzem DC został jeden z liderów Inicjatywy, Amintore Fanfani ${ }^{40}$. Wśród jego najbliższych współpracowników znaleźli się późniejsi czołowi politycy chadecji, m.in. Aldo Moro, Oscar Luigi Scalfaro oraz Mariano Rumor, którzy uzyskali istotny wpływ na kształtowanie bieżącej polityki partii.

Wraz z nadejściem młodego pokolenia skończyła się stosowana dotąd praktyka swoistego prymatu polityka DC piastującego aktualnie funkcję premiera nad aparatem partyjnym. Na znaczeniu zyskały centralne organy statutowe, a kluczowa pozycja w partii przypadła sekretarzowi i jego otoczeniu. Radykalnie zmienił się też model funkcjonowania DC oparty dotychczas w dużej mierze na wolontariacie aktywistów. Fanfani, który był gorącym zwolennikiem silnej i skutecznej „partii-maszyny” zdolnej do konkurowania na każdym polu z partią komunistyczną, postawił przede wszystkim na budowę dobrze zorganizowanych, sprawnych struktur obsadzonych przez etatowych funkcjonariuszy partyjnych. Jednocześnie w nowym kierownictwie wzięła górę koncepcja omnipotencji partii i przejmowania przez nią, w zastępstwie państwa, kontroli nad kolejnymi sektorami życia gospodarczego i publicznego kraju.

W sferze polityczno-gospodarczej nowe władze partii, uznające ograniczanie wpływów opozycji komunistycznej za jeden ze swoich priorytetów, wyszły z inicjatywą przewartościowania dotychczasowej strategii chadecji w kierunku jej większej wrażliwości na kwestie społeczne i otwarcia na umiarkowany lewicowy elektorat. Autorami koncepcji byli młodzi naukowcy katoliccy wywodzący się z Katolickiego Uniwersytetu w Mediolanie: Pasquale Saraceno, Giuseppe Lazzati, Giuseppe Dossetti i Arrigo Boldrini zaprzyjaźnieni z Fanfanim i stanowiący jego zaplecze intelektualne, związani ze środowiskiem tzw. Codice di Camaldoli ${ }^{41}$. Oceniając krytycznie szereg aspektów ówczesnego kapitalizmu europejskiego, próbowali oni programowo połączyć włoskie doświadczenia interwencjonizmu państwowego z okresu międzywojennego

39 E. Wiskemann, Italy since 1945, Macmillan-St. Martin’s Press, London 1971, s. 21.

40 Amintore Fanfani (1908-1999) - ekonomista, pisarz; w okresie międzywojennym opowiedział się po stronie faszyzmu, był zwolennikiem korporacjonizmu; w latach 1946-1953 był ministrem pracy, rolnictwa i spraw wewnętrznych w kolejnych rządach chadeckich.

${ }^{41}$ W lipcu 1943 r. w klasztorze w Camaldoli odbyło się konwenium młodych aktywistów Włoskiej Akcji Katolickiej (Azione Cattolica Italiana) i Włoskiej Federacji Studentów Katolickich (Federazione Universitaria Cattolica Italiana) poświęcone kierunkom rozwojowym włoskiej gospodarki po II wojnie światowej. Sformułowane wówczas zasady i koncepcje programowe zostały zebrane w dokumencie nazwanym Codice di Camaldoli, który miał w późniejszym okresie szeroki wpływ na programy gospodarcze DC. Głównym animatorami konwenium byli Sergio Paronetto, Pasquale Saraceno oraz Ezio Vanoni. W seminarium uczestniczyli też m.in. Aldo Moro, Giulio Andreotti, Giorgio La Pira, Emilio Taviani, Ferrucio Pergolesi, Giudo Gonella. S. Misiani, Lo schema Vanoni e il nuovo meridionalismo, w: Rivista, Scuola Superiore dell'economia e delle finanze, Centro Ricerche Documentazione Economica e Finanziaria (CRDEF), Roma 2004, s. 2. 
i pierwszych lat powojennych z ideałami gospodarki społecznej i zasadami sprawiedliwości wynikającymi z doktryny społecznej Kościoła. Proponowali m.in. rozwój akcjonariatu pracowniczego lub innych form uspołecznienia przedsiębiorstw, przy zachowaniu podstawowych instrumentów kapitalistycznego modelu zarządzania przedsiębiorstwami. Szczególnego znaczenia, ich zdaniem, nabierała w tym kontekście kwestia planowania traktowanego jako instrument wpływania na kierunki aktywności gospodarczej w celu urzeczywistniania wcześniej określonych założeń oraz jako niezbędny element osiągania koherencji w narodowej polityce gospodarczej ${ }^{42}$.

Poza utrzymaniem w gospodarce silnej obecności państwa i wprowadzeniem planowania nowe kierownictwo chadecji opowiedziało się też za złagodzeniem polityki monetarnej wcześniejszych rządów.

Zgodnie z linią programową przeforsowaną przez Fanfaniego na kongresie DC w Neapolu, powiązany z jego frakcją ówczesny minister budżetu Ezio Vanoni przedstawił na posiedzeniu rządu 29 grudnia 1954 r. oficjalny projekt i założenia wieloletniego programu rozwoju gospodarczego kraju pod nazwą „Dziesięcioletni plan rozwoju dochodów i zatrudnienia we Włoszech w latach 1955-1964”. Dokument, nazwany później od nazwiska jego promotora planem Vanoniego, został w istocie opracowany przez grupę ekspertów gospodarczych związanych ze Stowarzyszeniem na rzecz Rozwoju Przemysłu Południa (Associazione per lo Sviluppo dell'Industria nel Mezzogiorno, SVIMEZ). Zespołem kierował wspomniany już bliski współpracownik Fanfaniego, Pasquale Saraceno, rzeczywisty pomysłodawca dokumentu. Do współpracy przy opracowaniu dokumentu zostali zaproszeni w charakterze konsultantów znani ekonomiści zagraniczni, zwolennicy keynesizmu - Jan Tinbergen oraz Paul N. Rosenstein-Rodan. W różnych etapach prac studyjnych i przygotowawczych uczestniczyli też m.in. politycy związani z Codice di Camaldoli oraz znani lewicujący intelektualiści chadeccy - Nino Novacco, Georgio Ceriani Sebregondi i Claudio Napoleoni, co miało niemały wpływ na społeczną zawartość projektu ${ }^{43}$.

W warstwie teoretycznej plan Vanoniego nawiązywał wprost do keynesowskiej doktryny ekonomicznej, zarówno z punktu widzenia formułowanych celów polityki makroekonomicznej, do których należało przede wszystkim osiągnięcie i utrzymanie pełnego zatrudnienia w gospodarce, jak i proponowanego instrumentarium mającego prowadzić do ich realizacji, m.in. zwiększenia wydatków budżetowych i rozwoju

42 F. Ricciardi, Una modernizzazione mancata? L'IRI e $i$ „piani economici” dal dopoguerra al „miracolo Economico", w: Workshop nazionale dottorandi in storia contemporanea, Università degli Studi di Napoli, Napoli 2006, s. 7.

43 Ibidem, s. 14. 
inwestycji publicznych oraz umocnienia wpływów państwa w gospodarce ${ }^{44}$. Konstrukcja dokumentu opierała się z jednej strony na założeniu o konieczności określenia głównych kierunków rozwojowych kraju oraz zaplanowania i realizacji inwestycji uważanych z tego punktu widzenia za strategiczne, z drugiej - na założeniu, że polityce gospodarczej musi towarzyszyć skuteczniejsza niż dotąd polityka społeczna ukierunkowana na bardziej sprawiedliwą redystrybucję dochodu narodowego ${ }^{45}$.

W wymiarze społecznym plan Vanoniego miał dość lewicowe zabarwienie i w intencji jego autorów oraz części polityków chadeckich był odpowiedzią na polityczną ofensywę lewicy komunistycznej i lansowany przez nią program gospodarczy, tzw. Plan pracy ${ }^{46}$.

Plan Vanoniego formułował trzy zasadnicze cele: osiągnięcie w ciągu dziesięciu lat pełnego zatrudnienia w gospodarce, zmniejszenie dysproporcji gospodarczych między północną częścią kraju i biednym Południem (Mezzogiorno) oraz osiągnięcie trwałej równowagi w bilansie płatniczym ${ }^{47}$. Podstawowym instrumentem w tym zakresie miały stać się znaczące, głównie infrastrukturalne inwestycje państwa skoncentrowane w trzech dziedzinach: w tzw. sektorach napędowych, w budownictwie mieszkaniowym oraz w sektorach produkcyjnych obejmujących przemysł przetwórczy oraz usługi. Do sektorów „napędowych” odpowiedzialnych za tworzenie infrastruktury i warunków niezbędnych do przyspieszonego rozwoju pozostałych gałęzi gospodarki oraz mających wygenerować w początkowym okresie największą liczbę nowych miejsc pracy zaliczono rolnictwo (rewitalizacja nieużytków, prace melioracyjne), przedsiębiorstwa użyteczności publicznej (kolej, porty, lotniska, energetyka, gazownictwo, telekomunikacja, szpitale, szkoły) oraz roboty publiczne (drogi, mosty, infrastruktura wodno-kanalizacyjna). Traktowano je jednocześnie jako sferę kompetencji państwa, gdzie rząd miał pełnić funkcje koordynujące ${ }^{48}$.

Ogólna wartość inwestycji netto zakładanych w planie Vanoniego na lata 1955-1964 wynosiła blisko 24340 mld lirów (38,9 mld USD), z czego 43,7\% miały stanowić

44 V. Zamagni, Nuovo meridionalismo e intervento straordinario. La Svimez dal 1946 al 1950, Il Mulino, Bologna 1988, s. 30-34; A. Graziani, L’economia italiana 1945-1970, Il Mulino, Bologna 1972, s. 78-80.

45 S. Misiani, op.cit., s. 2.

46 Plan pracy, jako program gospodarczy Włoskiej Partii Komunistycznej, został po raz pierwszy zaprezentowany na kongresie Włoskiej Generalnej Konfederacji Pracy (CGIL) w 1950 r. Proponował zawarcie paktu społecznego opartego na założeniach doktryny Keynesa. Obiecywał ograniczenie przez związki zawodowe akcji rewindykacyjnych $\mathrm{w}$ zamian za prospołeczne inwestycje państwa, przede wszystkim w rolnictwie oraz na Południu. Proponował utworzenie szeregu instytucji o zasięgu ogólnokrajowym odpowiedzialnych m.in. za budownictwo socjalne, elektryfikację, rewitalizację nieużytków. Głównym źródłem finansowania Planu pracy miał być progresywny podatek od posiadanego majątku. G. Maione, op.cit., s. 6.

47 Le Plan Vanoni et léconomie italienne, „La documentation française” nr 2040, Presidénce de Conseil, Paris 1955, s. 3.

48 G. Ruffolo, Il piano Vanoni, Il Mulino, Bologna 1955, s. 5. 
wydatki w sektorach "napędowych”, 35,3\% - w sektorach produkcyjnych oraz 21\% - w budownictwie mieszkaniowym. Inwestycje miały wzrastać rocznie od 5\% w $1955 \mathrm{r}$. do $8 \%$ w latach $1957-60^{49}$. Ponadto przewidywano wydatki rzędu 10770 mld lirów (17,2 mld USD) na utrzymanie i odnowienie istniejącego aparatu produkcyjnego, co dawało w sumie 35107 mld lirów (56,2 mld USD) inwestycji brutto ${ }^{50}$. Łącznie miały one wzrosnąć o 98\% i osiągnąć w 1964 r. wartość 25,4\% PKB, wobec 20,5\% w 1954 r.

Podstawowymi źródłami finansowania inwestycji zakładanych w pierwszych czterech latach realizacji planu miały być wydatki własne przedsiębiorstw ( 5720 mld lirów), dotacje państwowe ( 680 mld lirów) i kapitał z zagranicy (320 mld lirów). Państwo miało finansować przede wszystkim rolnictwo, sektor usług publicznych, socjalne budownictwo mieszkaniowe oraz roboty publiczne. Szczególna rola w zarządzaniu wydatkami państwa w odniesieniu do przemysłu przypadła IRI. Miał on decydować m.in. o podziale środków, priorytetach inwestycyjnych oraz lokalizacji nowych przedsiębiorstw. Nadzorowane przez niego inwestycje miały być lokowane głównie w przemyśle stalowym, maszynowym oraz w energetyce, telekomunikacji, infrastrukturze drogowej, transporcie lotniczym i morskim.

$\mathrm{W}$ odniesieniu do pierwszego $\mathrm{z}$ trzech zdefiniowanych celów - polityki pełnego zatrudnienia - plan Vanoniego prognozował stworzenie w latach 1955-1964 około $3,2 \mathrm{mln}$ nowych miejsc pracy poza rolnictwem, $\mathrm{w}$ tym $1,6 \mathrm{mln} \mathrm{w}$ przemyśle oraz $1,6 \mathrm{mln}$ w transporcie, budownictwie i usługach, przewidywał też utrzymanie 800 tys. miejsc zagrożonych modernizacją aparatu wytwórczego i postępującym wzrostem wydajności pracy ${ }^{51}$. W kontekście zapisu o zmniejszaniu dysproporcji rozwojowych między Południem i Północą plan zakładał, że w latach 1955-1964 na regiony Mezzogiorno, które w 1954 r. zamieszkiwało 36\% populacji kraju, przypadnie 54\% ogółu inwestycji w rolnictwie, $36 \%$ - w dziedzinie usług publicznych, $48 \%$ - w budownictwie mieszkaniowym oraz $50 \%$ - w zakresie robót publicznych.

W przypadku trzeciego celu - osiągnięcia równowagi w bilansie płatniczym - plan zakładał przede wszystkim zwiększenie dynamiki wzrostu eksportu. Przewidywano, że w latach 1955-1964 zwiększy się on o 52\%, podczas gdy import wzrośnie o $42 \%$. Planowano również, że deficyt w obrotach handlowych wzrośnie o $21 \%$, jednak zostanie w całości zrekompensowany wpływami z turystyki zagranicznej, z opłat frachtowych oraz z przekazów pieniężnych od włoskich emigrantów ${ }^{52}$.

\footnotetext{
49 Le Plan Vanoni et l'économie italienne, op.cit., s. 9.

50 G. Ruffolo, op.cit., s. 6.

51 E. Vanoni, La politica economica degli anni degasperiani. Scritti e discorsi politici ed economici, Le Monnier, Firenze 1977, s. 344.

52 Le Plan Vanoni et léconomie italienne, op.cit., s. 13.
} 
Poza zdefiniowaniem celów i środków ich realizacji plan Vanoniego określał przewidywaną wartość najważniejszych wskaźników makroekonomicznych. PKB miał rosnąć w tempie 5\% rocznie, produkcja przemysłowa miała zwiększyć się łącznie o $82 \%$. Równocześnie zakładano wyhamowanie średniorocznej dynamiki wzrostu płac do 2,5\% oraz konsumpcji indywidualnej do 4,2\%. Miało to ułatwić wygospodarowanie dodatkowych środków na inwestycje z uzyskiwanych dochodów.

Na początku 1955 r. plan został zatwierdzony przez Izbę Deputowanych. W ślad za tym przy poszczególnych resortach powstało dziesięć komisji branżowych i terytorialnych odpowiedzialnych za przygotowanie wycinkowych, konkretnych programów inwestycyjnych na lata 1955-1958 i planów ich wdrażania. Funkcjonowanie komisji nadzorował Komitet ministrów ds. koordynacji planu. W 1956 r. powołano dodatkowo tzw. Komisję ds. zatrudnienia i dochodów, organ wykonawczy, którego przewodniczącym został Pasquale Saraceno ${ }^{53}$.

Już po pierwszych trzech latach realizacji planu okazało się, że jego założenia i projekcje znacząco rozmijały się z realnym stanem gospodarki i osiąganymi przez nią wynikami, a najważniejsze wskaźniki makroekonomiczne wyraźnie przekroczyły prognozowane wartości. W latach 1955-1957 wielkość inwestycji brutto wzrastała rocznie średnio o $12 \%$, wobec 6-7\% założonych w planie, osiągając poziom $22,6 \%$ $\mathrm{PKB}^{54}$. PKB zwiększył się w tym okresie o 27\% (średniorocznie o 8,2\%). Jego dynamika wzrostowa była o ponad $60 \%$ wyższa od prognozowanej. Tak wysoki wzrost był przede wszystkim efektem szybkiego rozwoju produkcji przemysłowej, która w latach 1955-1957 zwiększyła się o 27,5\% (średniorocznie o 8,5\%), podczas gdy plan prognozował jej wzrost na poziomie $6,1-6,2 \%$ rocznie. $Z$ kolei na dynamikę produkcji przemysłowej wpływał wysoki poziom popytu wewnętrznego, systematycznie rosnący eksport oraz znaczący wzrost wydajności pracy, który w tym okresie wyniósł dla całego przemysłu $15,5 \%{ }^{55}$. W stosunku do prognoz zawartych w planie znacznie wyższe wskaźniki odnotowano również w handlu zagranicznym. Wymiana handlowa Włoch w latach 1955-1957 rozwijała się w tempie około 14,5\% rocznie ${ }^{56}$ i wzrosła łącznie o 52,6\%, przekraczając o 4,6 pkt. proc. wartość przewidzianą na 1964 r.

Dwukrotnie szybciej niż prognozowano w planie Vanoniego rosły przeciętne zarobki w gospodarce. Tempo wzrostu płac nominalnych w latach 1955-1957 wyniosło średnio 5,2\% rocznie i było niższe zarówno od stopy wzrostu produkcji przemysłowej (8,5\%), jak i wydajności pracy (5,3\%). Z jednej strony tendencja ta skutecznie hamowała inflację, której średnia stopa w omawianym okresie nie przekroczyła

${ }^{53}$ F. Ricciardi, op.cit., s. 16.

54 ISTAT, Annuario statistico 1960, Roma 1960, s. 355.

${ }_{55}$ Czynniki wzrostu wydajności i dochodu we Włoszech w latach 1951-63, GUS, Warszawa 1970, s. 9.

56 A. Cardini, Il miracolo economico italiano, Il Mulino, Bologna 2006, s. 31. 
2,4\%, z drugiej - znacząco ograniczała wzrost kosztów pracy, co w ostatecznym efekcie przekładało się m.in. na większą konkurencyjność wielu włoskich towarów na rynkach międzynarodowych i ułatwiło w kolejnych latach dynamiczną ekspansję włoskiego eksportu ${ }^{57}$.

Wraz ze wzrostem dochodów rosła konsumpcja indywidualna. W latach 1955-1957 zwiększyła się ona w skali całego kraju o 21,3\%, a jej dynamika wzrostowa (średnio $6,6 \%$ rocznie) była o ponad 50\% wyższa niż zakładano.

Plan Vanoniego od początku był kontestowany zarówno przez opozycję parlamentarną, jak i dużą część środowisk gospodarczych. Ze względu na lewicowe zabarwienie dokument spotkał się też z jawną obstrukcją ze strony chadeckich konserwatystów i stał się jedną z zasadniczych płaszczyzn trwającego od 1954 r. sporu między partyjną lewicą i prawicą na tle otwarcia się DC na lewicę niekomunistyczną ${ }^{58}$. Pod wpływem zaostrzającego się wewnątrzpartyjnego konfliktu i w sytuacji, w której większość zakładanych w planie wskaźników makroekonomicznych została znacznie przekroczona in plus, rząd zaprzestał de facto jego wdrażania. Od 1957 r. likwidowano stopniowo kolejne komisje branżowe, a w 1959 r. rozwiązano funkcjonującą przy Radzie Ministrów Komisję ds. zatrudnienia i dochodów.

Generalnie, plan Vanoniego okazał się mało skutecznym instrumentem w sterowaniu żywiołowo rozwijającą się gospodarką. Zasadniczym mankamentem dokumentu było nadmierne skoncentrowanie się na aspektach czysto społecznych oraz niedostosowanie jego założeń makroekonomicznych do realiów i potrzeb szybko rozwijającej się gospodarki rynkowej. Autorzy planu zaprezentowali w tym zakresie zbyt konserwatywne oraz minimalistyczne podejście, akcentując wiodącą rolę tradycyjnych wówczas działów gospodarki, które uznali za „napędowe” i nie uwzględniając w nim rosnącego potencjału i dynamiki nowoczesnych gałęzi przemysłu, m.in. chemicznego i motoryzacyjnego oraz gałęzi produkujących dobra konsumpcyjne, które pod koniec lat 50., w miejsce tzw. sektorów napędowych, stały się rzeczywistymi kołami zamachowymi gospodarki. Wyrazem tej „krótkowzroczności” było m.in. zaplanowanie relatywnie niskich wydatków na rozwój infrastruktury drogowej, podczas gdy już na początku lat 50. ujawniły się symptomy zapowiadające boom motoryzacyjny, a produkcja samochodów osobowych rosła w tempie $15-20 \%$ rocznie ${ }^{59}$.

57 Ibidem, s. 31.

58 S. Cafiero, Storia dell'intervento straordinario nel Mezzogiorno (1950-1993), Piero Lacaita Editore, Manduria 2000, s. 48.

59 Wg planu Vanoniego wydatki na infrastrukturę drogową w dziesięcioleciu 1955-1964 miały wynieść 1150 mld lirów (1,84 mld USD), co stanowiło około 3,5\% ogółu zakładanych inwestycji brutto w tym okresie. G. Maione, op.cit., s. 10, 21. 
Plan Vanoniego, w okresie kiedy był realizowany, nie odegrał przypisanej mu zasadniczej roli w zakresie ograniczania bezrobocia i niwelowania zapóźnień rozwojowych Południa, jednak dzięki uruchomieniu na dużą skalę inwestycji, w tym infrastrukturalnych, był jednym z czynników, które przyczyniły się do rozkwitu gospodarki w latach 1958-1963.

\section{Sektor państwowy w latach ożywienia i boomu gospodarczego (1955-1963)}

W czerwcu 1955 r. premierem został Antonio Segni ${ }^{60}$, chadecki polityk związany z frakcją ówczesnego sekretarza DC Amintore Fanfaniego, zdecydowany zwolennik państwowego interwencjonizmu. Za jego dwuletniej kadencji sektor państwowy stał się uprzywilejowanym podmiotem i inwestorem na włoskim rynku, ale jednocześnie wygodnym i skutecznym narzędziem władz w realizacji polityki gospodarczej nawiązującej w wielu aspektach do doktryny ekonomicznej Keynesa. Rząd scedował na niego zadania m.in. w zakresie przezwyciężania różnic rozwojowych między Południem i Północą kraju, kształtowania strategii inwestycyjnych na obszarach zacofanych gospodarczo, rozwoju inwestycji publicznych oraz udziału w realizacji polityki zatrudnienia. Instytucjonalnym tego wyrazem było utworzenie w grudniu 1956 r. Ministerstwa Udziałów Państwowych (Ministero delle Partecipazioni Statali), które w założeniach miało przede wszystkim definiować priorytety inwestycyjne i zasadnicze kierunki aktywności gospodarczej. De facto jednak urząd ten szybko przekształcił się w czysto biurokratyczną strukturę, która poprzez stosowany system dotacji i zachęt finansowych wobec podległych mu przedsiębiorstw, a także decydujący wpływ na obsadę zarządów stała się narzędziem umacniania wpływów chadecji w newralgicznych działach gospodarki ${ }^{61}$.

Na rządowej polityce interwencjonizmu zyskał szczególnie IRI. W 1956 r. holding otrzymał na wyłączność koncesję na rozbudowę i obsługę całej krajowej sieci telefonicznej oraz został jednym z głównych rozgrywających w programie budowy sieci autostrad.

Już wkrótce po zaprzysiężeniu rząd Segniego, w pewnej mierze pod presją lobby motoryzacyjnego postulującego zwiększenie środków finansowych na infrastrukturę

60 Antonio Segni (1891-1972) - prawnik, profesor uniwersytetu w Perugii; w okresie międzywojennym polityk Partii Ludowej, po wojnie - Chrześcijańskiej Demokracji; w latach 1962-1964 był prezydentem republiki.

${ }^{61}$ G. Maione, op.cit., s. 7. 
drogową w stosunku do kwot prognozowanych w planie Vanoniego, przyjąl program finansowania i budowy autostrad (tzw. Legge Romita), który przewidywał połączenie siecią autostradową o długości 3,2 tys. km wszystkich regionów ${ }^{62}$ kraju w perspektywie 25 lat. Z uwagi na dużą skalę projektu założono, że w realizacji programu weźmie udział zarówno kapitał państwowy, jak i prywatny. Administrowanie programem powierzono istniejącej od 1946 r. państwowej spółce pod nazwą Autonomiczna Narodowa Agencja Dróg Państwowych (Azienda Nazionale Autonoma delle Strade Statali, ANAS), której jedynym udziałowcem było ministerstwo finansów. W $1956 \mathrm{r}$. ANAS zawarła pierwszy, w ramach programu, kontrakt na budowę i obsługę kluczowej dla gospodarki włoskiej autostrady między Mediolanem i Neapolem. Wykonawcą została spółka-córka IRI pod nazwą Società Autostrade Concessioni e Costruzioni. Budowa drogi postępowała w rekordowym tempie $94 \mathrm{~km}$ rocznie, mimo że $1 / 3$ jej odcinków przebiegało przez trudne tereny górskie. Koszt całej, ukończonej w 1964 r. 755-kilometrowej trasy wyniósł 272 mld lirów (435,2 mln USD), z czego około 90 mld lirów stanowiło wartość robót publicznych finansowanych z budżetu państwa ${ }^{63}$. Autostrada stała się jednym z symboli skoku cywilizacyjnego Włoch i sukcesu przemian gospodarczych w tym kraju, miała jednak przede wszystkim wymiar ekonomiczny i społeczny. Z jednej strony połączyła bogatą Północ z biednym Południem, przyczyniając się do zmniejszenia izolacji, rozwoju turystyki i ożywienia gospodarczego szeregu zacofanych obszarów kraju, z drugiej - stała się zaczątkiem nowoczesnej sieci autostradowej.

Wobec wcześniejszych niepowodzeń państwa w zakresie niwelowania zapóźnień rozwojowych Mezzogiorno ${ }^{64}$ wobec reszty kraju i przyciągnięcia tam na większą skalę prywatnego kapitału inwestycyjnego, IRI oraz w mniejszym stopniu ENI przypadła rola głównych wykonawców polityki industrializacji i stymulowania rozwoju ekonomicznego tej części kraju. Formalnie zostało to usankcjonowane ustawą nr 634 z 1957 r., w której parlament nałożył na nie obowiązek lokowania na Południu 40\% inwestycji o charakterze produkcyjnym oraz $60 \%$ wszystkich nowych inwestycji ${ }^{65}$.

Do drugiej połowy lat 50. władze centralne niezmiennie deklarowały trzy podstawowe kierunki działania na rzecz Mezzogiorno: rozwój infrastruktury, ułatwienia dla kapitału prywatnego oraz bezpośrednie inwestycje państwa. Kluczowym instrumentem tej strategii miała być powołana w 1950 r. tzw. Kasa Południa, instytucja prawa

\footnotetext{
62 Odpowiednik województwa w Polsce.

63 ISTAT, Annuario statistico 1960, op.cit., s. 218; ISTAT, Annuario statistico 1964, Roma 1964, s. 232.

64 Do Mezzogiorno zaliczano osiem południowych regionów kraju: Sycylię, Sardynię, Kalabrię, Apulię, Molise, Kampanię, Abruzję i Basilicatę.

65 G. Crainz, Storia del miracolo italiano. Culture, identitá, trasformazioni fra anni cinquanta e sessanta, Donzelli, Roma 1996, s. 83-85; ISTAT, Statistiche storiche dell'Italia, op.cit., s. 127-128.
} 
publicznego dysponująca budżetem w wysokości 1000 mld lirów (1600 mln USD) ${ }^{66}$, której statutowym zadaniem było finansowanie i koordynowanie działań interwencyjnych państwa, mających służyć ekonomicznemu i społecznemu rozwojowi Południa ${ }^{67}$. Działania Kasy Południa miały koncentrować się na tworzeniu infrastruktury i przyciąganiu prywatnego kapitału inwestycyjnego poprzez ciągle rozbudowywany system zachęt podatkowych i bodźców finansowych. Skuteczność tych przedsięwzięć okazała się jednak niewspółmiernie niska w stosunku do ponoszonych kosztów, a skala napływu inwestorów, zwłaszcza tych największych, najbardziej pożądanych, była niewielka. Decydująca okazała się w tym wypadku logika rachunku ekonomicznego - mimo ulg, inwestowanie na zacofanym, biednym, pozbawionym infrastruktury Południu było znacznie kosztowniejsze i bardziej ryzykowne, a realna stopa zwrotu kapitału niższa niż w pozostałych, lepiej rozwiniętych regionach. W tych warunkach liczący się włoscy przedsiębiorcy byli bardziej zainteresowani ekspansją zewnętrzną niż podejmowaniem ryzyka na Południu. Region ten omijał również kapitał zagraniczny, koncentrując swoje przedsięwzięcia głównie na północy Włoch ${ }^{68}$.

$\mathrm{W}$ stosunku do stosowanego dotąd instrumentarium wspomniana ustawa $\mathrm{nr} 634$ stanowiła poważną zmianę jakościową. Oprócz narzucenia na przedsiębiorstwa państwowe minimalnych poziomów inwestycji na Południu, obligowała je do przygotowywania pięcioletnich programów inwestycyjnych w tej części kraju ze wskazaniem planowanego poziomu zatrudnienia, wartości inwestycji i ich lokalizacji. Firmy państwowe były ponadto zobowiązane do zakupu $30 \%$ potrzebnych im materiałów i surowców od lokalnych przedsiębiorstw, zapis ten jednak pozostał w dużej mierze martwy, m.in. z uwagi na brak wystarczających źródeł zaopatrzenia ${ }^{69}$.

W myśl ww. ustawy podstawowym narzędziem industrializacji Mezzogiorno miały stać się tzw. bieguny rozwoju przemysłowego lokowane w największych miastach regionu liczących powyżej 200 tys. mieszkańców oraz „ogniwa industrializacji” przypisane do mniejszych ośrodków miejskich ${ }^{70}$. Przewidziano utworzenie 43 takich obszarów, m.in. wokół Neapolu, Salerno, Caserty, Bari, Brindisi, Taranto, Pescary, Katanii, Syrakuz, Palermo i Cagliari. Miały one objąć 1/5 terytorium południowych Włoch i blisko 50\% ludności regionu. Podejmujące w nich działalność podmioty gospodarcze otrzymywały m.in. gwarancje kredytowe oraz pięcioletnie zwolnienie z połowy podatku dochodowego.

66 G. Zampaglione, Italy, Ernest Benn Limited, London 1956, s. 261.

67 E. Wiskemann, op.cit., s. 19.

68 D. Sassoon, Contemporary Italy. Politics, economy and society since 1945, Longman, London 1986, s. 35.

69 W. Trznadel, op.cit., s. 150, 155.

${ }^{70}$ N. Kogan, A Political History of Italy. The postwar years, Praeger, New York 1983, s. 138. 
Duża liczba ustanowionych w 1957 r. „biegunów” i „ogniw przemysłowych” oraz ich nadmierny zasięg terytorialny, ustalany niejednokrotnie na wyrost przez ambitnych lokalnych działaczy, nie korespondowały z liczbą potencjalnych inwestorów oraz ich realnymi, często ograniczonymi możliwościami finansowymi. W efekcie następowało niekorzystne rozproszenie środków, utrudniając całościowy i równomierny rozwój poszczególnych stref, zwłaszcza tych zlokalizowanych wokół małych ośrodków. Część z nich z powodu braku inwestorów funkcjonowała de facto tylko na papierze. Innym problemem była niedostosowana do lokalnych warunków wielka skala niektórych inwestycji realizowanych głównie przez koncerny państwowe. Ewidentnym tego przykładem są rafinerie w Gela i Cagliari, huta w Taranto oraz zakłady chemiczne w Brindisi. Te kosztowne zakłady charakteryzujące się najwyższym wskaźnikiem nakładów kapitałowych na jednego zatrudnionego i długim okresem zwrotu kapitału zostały wybudowane w dużej mierze w oderwaniu od miejscowych realiów społecznych oraz gospodarczych. Przy ich lokalizacji nie uwzględniono ani słabo rozwiniętej infrastruktury, ani braku wykwalifikowanych kadr. W konsekwencji, mimo dużej skali przedsięwzięcia, fabryki te nie były np. w stanie wchłonąć w oczekiwanym stopniu lokalnej, słabo wykształconej siły roboczej i musiały sprowadzać większość specjalistów z centralnych i północnych części Włoch. Co więcej, produkcja tych zakładów nie pobudzała w istotny sposób rozwoju innych przedsiębiorstw i wzrostu gospodarczego regionu, bowiem większość ich wyrobów trafiała, jako półprodukty, do przemysłu na Północy. Inwestycje te, określane przez ówczesne media ironicznym mianem „katedr na pustyni”, stały się symbolem niskiej efektywności polityki rozwojowej władz wobec Mezzogiorno. Jednak bez względu na ocenę skuteczności państwa w tym zakresie należy podkreślić, że w odróżnieniu od regionów centralnych i północnych Włoch, gdzie na tempo wzrostu gospodarczego wpływała w decydującej mierze akumulacja kapitału prywatnego, jakikolwiek rozwój Południa nie byłby możliwy bez liczącego się zaangażowania kapitałowego państwa.

W 1958 r. włoska gospodarka weszła w sześcioletnią fazę bardzo dynamicznego, najszybszego od zakończenia II wojny światowej wzrostu. O skali i tempie rozwoju zadecydowało kilka czynników, m.in.:

- polityka gospodarcza władz po 1957 r. ukierunkowana na przyspieszony rozwój wybranych gałęzi przemysłu oraz stymulowanie eksportu, który uznano za jeden z najważniejszych czynników prorozwojowych;

- unowocześnienie aparatu produkcyjnego, wprowadzenie nowych, sprawdzonych w USA rozwiązań technicznych i organizacyjnych podnoszących wydajność produkcji;

- rozwój rynku wewnętrznego i konsumpcji artykułów trwałego użytku (m.in. samochody, urządzenia gospodarstwa domowego); 
- wielkie zasoby taniej siły roboczej będące konsekwencją wysokiego przyrostu naturalnego i dużego bezrobocia oraz niska, w stosunku do tempa rozwoju gospodarczego, dynamika wzrostu płac pracowniczych, co przekładało się na relatywnie niskie koszty produkcji i zwiększenie konkurencyjności włoskich produktów na rynkach międzynarodowych;

- wejście Włoch do Europejskiej Wspólnoty Gospodarczej w 1957 r., co otworzyło drogę do szybkiego wzrostu eksportu tanich produktów włoskich na rynek wspólnotowy ${ }^{71}$.

Dynamikę rozwojową włoska gospodarka zawdzięczała zwłaszcza wysokiemu poziomowi inwestycji, w dużej mierze z udziałem państwa i przedsiębiorstw państwowych. W latach 1958-1963 stopa inwestycji rosła średnio 9,7\% rocznie, a ich poziom zwiększył się z 21,5\% PKB w 1958 r. do 24,5\% PKB w 1963 r., notując swoje maksimum w 1962 r. $(25,5 \%)^{72}$. Ponad 22,4\% ogółu inwestycji brutto o wartości około 6850 mld lirów (10,9 mld USD) stanowiły inwestycje państwa. Z jednej strony składały się na nie roboty publiczne skoncentrowane głównie w dziedzinach o charakterze infrastrukturalnym, $\mathrm{z}$ drugiej - nakłady inwestycyjne poniesione przez przedsiębiorstwa kontrolowane przez państwo za pośrednictwem IRI i ENI.

Wartość robót publicznych wyniosła w omawianym okresie łącznie 4360 mld lirów (7,0 mld USD). Największy udział w tej kwocie miało mieszkalnictwo socjalne (22\%) oraz budowa dróg (21\%), w tym realizowany od 1956 r. program budowy autostrad.

Tabela 1. Wartość robót publicznych w latach 1958-1963 (w mld lirów)

\begin{tabular}{|l|r|r|r|r|r|r|r|}
\hline \multicolumn{1}{|c|}{ Dziedzina } & 1958 & 1959 & 1960 & 1961 & 1962 & 1963 & $\begin{array}{c}1963 / 1957 \\
\text { (w \%) }\end{array}$ \\
\hline Drogi & 115,2 & 151,5 & 195,2 & 217,8 & 201,5 & 222,9 & 202,6 \\
\hline Kolej & 26,4 & 36,8 & 42,5 & 41,5 & 37,9 & 43,3 & 195,0 \\
\hline Melioracje & 70,4 & 72,4 & 80,0 & 92,8 & 97,0 & 131,0 & 222,4 \\
\hline Wodociągi & 17,8 & 27,1 & 29,4 & 37,4 & 32,0 & 19,2 & 106,7 \\
\hline Kanalizacja & 56,6 & 71,8 & 75,4 & 87,0 & 81,9 & 82,8 & 146,5 \\
\hline Obiekty użyteczności publicznej & 81,8 & 97,8 & 104,7 & 111,8 & 114,3 & 120,1 & 159,5 \\
\hline Budownictwo socjalne & 123,7 & 254,8 & 211,8 & 163,0 & 117,8 & 88,8 & 79,7 \\
\hline Inne & 37,6 & 57,9 & 56,8 & 48,8 & 35,6 & 35,2 & 112,5 \\
\hline Ogótem & 529,5 & 770,1 & 795,8 & 800,1 & 718,0 & 743,3 & 153,7 \\
\hline
\end{tabular}

Źródło: Oprac. własne na podstawie: ISTAT, Annuario statistico 1960, Roma 1960, s. 218-219; ISTAT, Annuario statistico 1964, Roma 1964, s. 232.

${ }^{71}$ D. Sassoon, op.cit., s. 31.

72 S. Vinci, Il ruolo delle esportazioni nello sviluppo economico italiano del periodo 1951-1962, w: Lo sviluppo di uneconomia aperta, Esi, Napoli 1969 s. 92; ISTAT, Annuario statistico 1964, op.cit., s. 373. 
Nakłady inwestycje ENI, głównie w przemyśle petrochemicznym, sięgnęły 750 mld lirów, natomiast IRI - 1740 mld lirów. Około 60\% swoich wydatków Instytut pokrywał ze źródeł własnych, reszta była finansowana przez rynek finansowy, głównie w drodze emisji akcji lub obligacji. Poza gałęziami gospodarki, które dotąd były domeną IRI, jak hutnictwo, przemysł stoczniowy i infrastruktura, w inwestycyjnym zainteresowaniu holdingu znalazły się m.in. szybko rozwijające się działy przemysłu elektromaszynowego, telekomunikacja, transport lotniczy oraz radio i telewizja ${ }^{73}$.

Tabela 2. Wartość inwestycji IRI w poszczególnych sektorach gospodarki w latach 1958 i 1963 (w mld lirów)

\begin{tabular}{|l|c|c|c|c|}
\hline \multirow{2}{*}{ Sektor } & \multicolumn{2}{|c|}{1958} & \multicolumn{2}{c|}{1963} \\
\cline { 2 - 5 } & wartość & \% ogółu & wartość & $\%$ ogółu \\
\hline Radio i telewizja & 8,0 & 3,0 & 11,5 & 3,2 \\
\hline Transport morski & 24,0 & 9,0 & 38,5 & 10,7 \\
\hline Transport lotniczy & 8,0 & 3,0 & 17,5 & 4,9 \\
\hline Autostrady & 32,0 & 12,0 & 53,5 & 14,9 \\
\hline Przemysł maszynowy & 23,0 & 8,6 & 43,5 & 12,1 \\
\hline Telekomunikacja & 69,0 & 25,8 & 91,0 & 25,3 \\
\hline Hutnictwo & 29,0 & 10,9 & 100,0 & 27,8 \\
\hline Energetyka & 71,0 & 26,6 & 0,0 & 0,0 \\
\hline Inne & 3,0 & 1,1 & 4,5 & 1,1 \\
\hline Razem & 267,0 & 100,0 & 360,0 & 100,0 \\
\hline
\end{tabular}

Źródło: Oprac. własne na podstawie: S. Różycki, Kierunki rozwoju gospodarki włoskiej po II wojnie światowej, Wydawnictwo CJNTiE, Warszawa 1966, s. 3; G. Maione, Spesa pubblica o consumi privati?, „Italia Contemporanea” 2003, nr 231, s. 19.

W latach 1958-1963, pod działaniem ustawy nr 634, 25\% wszystkich włoskich inwestycji brutto wchłonęło Mezzogiorno ${ }^{74}$. Analogiczny średni wskaźnik liczony tylko dla przedsiębiorstw państwowych był wyższy (33\%), jednak przez cały okres utrzymywał się poniżej ustawowego $40 \%$ progu. W inwestycjach sektora publicznego uczestniczyły na Południu obie największe państwowe grupy kapitałowe. ENI, którego inwestycje wyniosły w tym okresie około 250 mld lirów (400 mln USD), był zaangażowany głównie $\mathrm{w}$ przedsięwzięcia w przemyśle petrochemicznym, w tym w budowę rafinerii w Gela na Sycylii oraz w Cagliari na Sardynii, natomiast grupa IRI z wydatkami 389 mld lirów $(622,4$ mln USD) koncentrowała się przede wszystkim

73 G. Maione, op.cit., s. 13.

74 ISTAT, Annuario statistico 1964, op.cit., s. 385. 
na energetyce, telekomunikacji oraz infrastrukturze ${ }^{75}$. Kwotowy i procentowy podział inwestycji IRI przedstawiał się następująco (tabela 3):

Tabela 3. Podział inwestycji grupy IRI w regionach Południa w latach 1958-1963

\begin{tabular}{|l|c|c|}
\hline \multicolumn{1}{|c|}{ Sektor } & Wartość (w mld lirów) & Udział w skali kraju (w \%) \\
\hline Energetyka & 171 & 56,8 \\
\hline Telekomunikacja & 53 & 20,1 \\
\hline Autostrady & 42 & 33,6 \\
\hline Hutnictwo & 17 & 10,0 \\
\hline Przemysł maszynowy & 34 & 30,6 \\
\hline Transport morski & 41 & 36,0 \\
\hline Transport lotniczy & 21 & 38,0 \\
\hline Inne & 10 & 27,1 \\
\hline Razem & 389 & 33,2 \\
\hline
\end{tabular}

Źródło: Oprac. własne na podstawie: F. Ricciardi, Una modernizzazione mancata? L'IRI e i "piani economici” al „miracolo economico”, w: Workshop nazionale dottorandi in storia contemporanea, Università degli Studi di Napoli, Napoli 2006, s. 20.

W 1963 r. IRI stał się drugą pod względem wielkości kapitału grupą przemysłową w Europie Zachodniej, kontrolował ponad 130 przedsiębiorstw zgrupowanych głównie w pięciu branżowych subholdingach: STET SpA (telekomunikacja), Finmare SpA (transport morski), Finsider SpA (hutnictwo), Finmeccanica SpA (przemysł maszynowy) i Fincantieri SpA (przemysł stoczniowy), zatrudniał 260 tys. pracowników, a całkowita wartość rynkowa jego aktywów przekroczyła 1100 mld lirów $(1,8 \text { mld USD })^{76}$.

Najszybciej rozwijającym się działem włoskiej gospodarki w latach 1958-1963 był przemysł. Realizowana po 1957 r. tzw. polityka przyspieszenia przemysłowego stanowiąca kluczowy element chadeckiej strategii ekspansji gospodarczej zakładała $\mathrm{z}$ jednej strony stymulowanie rozwoju wybranych gałęzi, a niekiedy $\mathrm{w}$ ich ramach nawet konkretnych firm, charakteryzujących się dużą dynamiką wzrostową i jednocześnie wysokim potencjałem eksportowym, $\mathrm{z}$ drugiej - aktywne wspieranie rozwoju produkcji eksportowej, zwłaszcza wyrobów wysoko przetworzonych i o dużej rentowności. Do urzeczywistnienia tych celów państwo wykorzystywało szereg instrumentów finansowych oraz celnych. Należały do nich m.in. preferencyjne kredyty inwestycyjne i eksportowe ze środków budżetowych, ulgi w podatku dochodowym płaconym przez przedsiębiorstwa lub wakacje podatkowe $\mathrm{z}$ tytułu realizowanych inwestycji proeksportowych oraz ulgi i zwolnienia celne na import dóbr inwestycyjnych

75 F. Ricciardi, op.cit., s. 20.

76 H. Lefebvre, Lo Stato, 3. Il modo di produzione statuale, Dedalo libri, Bari 1977, s. 200. 
i surowców. Uprzywilejowanym statusem cieszyła się zwłaszcza metalurgia, tzw. nowa chemia, petrochemia oraz przemysł elektromaszynowy, a w jego ramach branże produkujące dobra trwałego użytku ${ }^{77}$. Większość z nich wykazywała najwyższą spośród wszystkich działów dynamikę wzrostową. W omawianym okresie zwiększyły one produkcję od $93 \% \mathrm{w}$ przypadku branży gumowej do $180 \% \mathrm{w}$ przypadku przemysłu włókien sztucznych, podczas gdy wskaźnik dla całego przemysłu wyniósł 72,1\% ${ }^{78}$.

\section{Rysunek 3. Najważniejsze firmy w strukturze IRI w $1963 \mathrm{r}$.}

\section{IRI}
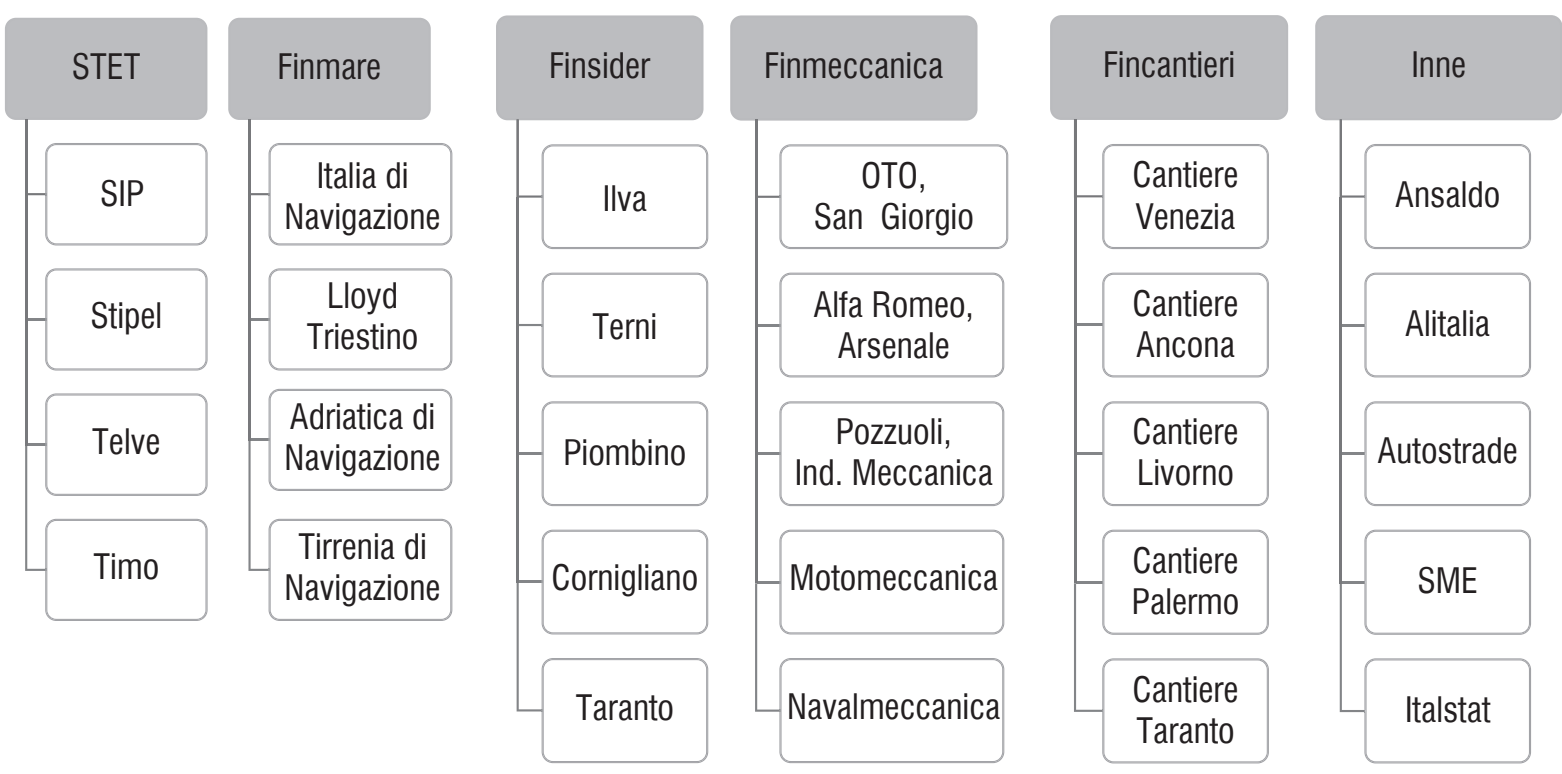

Źródło: Oprac. własne na podstawie: P. Saraceno, Il sistema delle imprese a partecipazione statale nell'esperienza italiana, Giuffrè, Milano 1975, s. 43-140.

W 1963 r. indeks produkcji najważniejszych gałęzi włoskiego przemysłu przedstawiał się następująco (rysunek 4):

77 A. Graziani, op.cit., s. 55-58, 162-167.

78 N. Kogan, op.cit., s. 131; ISTAT, Annuario statistico 1964, op.cit., s. 207. 
Rysunek 4. Indeks produkcji wybranych gałęzi przemysłu w $1963 \mathrm{r}$.

$(1957$ r. = 100, w mln lirów)

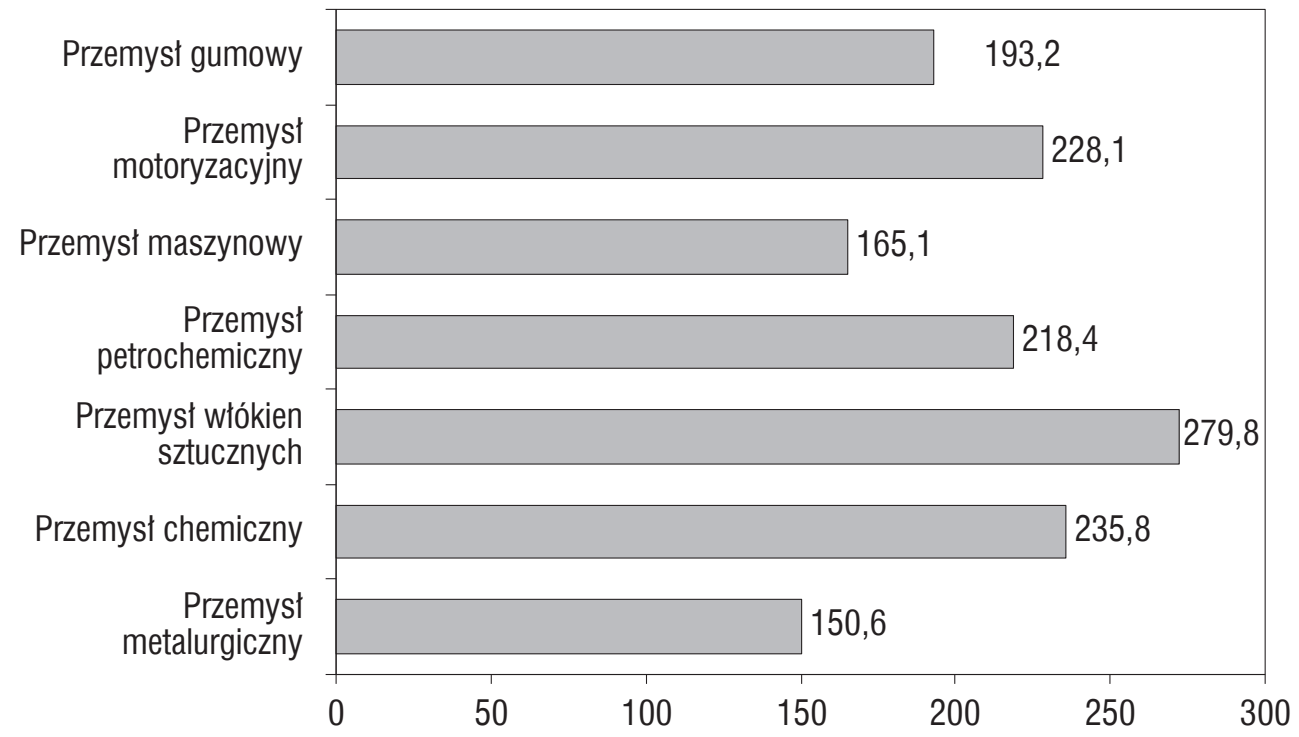

Źródło: Oprac. własne na podstawie: ISTAT, Annuario statistico 1964, Roma 1964, s. 207.

W kluczowych, a także najszybciej rozwijających się branżach włoskiego przemysłu znaczący udział miały przedsiębiorstwa państwowe. Dotyczyło to zwłaszcza hutnictwa, przemysłu chemicznego oraz maszynowego.

Hutnictwo, którego produkcja opierała się głównie na imporcie podstawowych surowców, zostało gruntownie zrestrukturyzowane i zmodernizowane już na początku lat 50. Rozwój branży w latach 1958-1963 był efektem znaczącego wzrostu inwestycji, które w 1963 r. sięgnęły 150 mld lirów ( $240 \mathrm{mln}$ USD), wobec niespełna 50 mld lirów (80 mln USD) w 1958 r. Na dynamikę wzrostową całej metalurgii w największym stopniu wpływał segment stalowy. W stosunku do 1957 r. produkcja surówki żelaza w 1963 r. była większa o 80,5\%, a stali surowej i wyrobów walcowanych odpowiednio o $49,6 \%$ oraz o $56,3 \%^{79}$. Hutnictwo było domeną państwa. Poprzez przedsiębiorstwa należące do IRI kontrolowało ono aż 90\% rynku surówki żelaza i 58\% rynku stali ${ }^{80}$.

$\mathrm{W}$ przemyśle chemicznym istotnym działem był sektor paliw płynnych w całości należący do koncernu ENI, bazujący w 96\% na importowanej ropie. W latach 1958-1963, dzięki wybudowaniu nowych, dużych rafinerii w Gela na Sycylii i w Pavii w Lombardii, branża zwiększyła blisko dwukrotnie swoje zdolności przerobowe z 26 mln t ropy naftowej w $1957 \mathrm{r}$. do $43 \mathrm{mln}$ t w $1963 \mathrm{r}^{81}$ Ogólna produkcja wzrosła

79 ISTAT, Annuario statistico 1964, op.cit., s. 215.

80 R. Rosario, Breve storia della grande industria in Italia, Mondadori, Milano 1988, s. 242-243.

81 Ibidem, s. 230. 
w tym okresie o $118,4 \%$, w tym benzyny o $134 \%$, oleju napędowego o $105,6 \%$ oraz oleju opałowego o $161,7 \%^{82}$. Najważniejszymi czynnikami stymulującymi rozwój tego działu był boom motoryzacyjny we Włoszech, rosnący eksport produktów naftowych, który w $1963 \mathrm{r}$. przekroczył 1/3 ich krajowej produkcji oraz wysoki popyt na produkty porafinacyjne ze strony tzw. nowej chemii produkującej m.in. żywice syntetyczne, masy plastyczne i kauczuk syntetyczny.

W najszerszym zakresie sektor państwowy był obecny w branży maszynowej będącej głównym producentem dóbr inwestycyjnych i urządzeń dla pozostałych działów gospodarki oraz dostawcą dóbr konsumpcyjnych trwałego użytku.

W przemyśle motoryzacyjnym IRI kontrolował około $12 \%$ rynku samochodowego poprzez spółkę Alfa Romeo SpA, która specjalizowała się w produkcji aut luksusowych oraz klasy średniej. Branża motoryzacyjna, której dynamika wzrostowa sięgała od 15,9\% w 1958 r. do 25,9\% w 1963 r. ${ }^{83}$, miała największy, ze wszystkich gałęzi wytwarzających dobra konsumpcyjne, wpływ na pobudzanie rozwoju branż kooperujących, m.in. przemysłu elektrotechnicznego, gumowego, szklarskiego, chemicznego ${ }^{84}$. Każde 1000 lirów produkcji tego sektora generowało wzrost produkcji całego przemysłu o 2000 lirów oraz wzrost eksportu o 210 lirów ${ }^{85}$.

W przemyśle zbrojeniowym na początku lat 60 . blisko $70 \%$ produkcji pochodziło z zakładów zarządzanych przez należący do IRI subholding Finmeccanica SpA. Niemal do końca lat 50. zbrojeniówka we Włoszech znajdowała się w powijakach, najpierw ze względu na ograniczenia narzucone przez traktat pokojowy z 1947 r., później, po ich zniesieniu w 1950 r., z powodu zmonopolizowania włoskiego rynku przez USA, które dostarczały znaczną część uzbrojenia bezpłatnie. Od 1958 r., w dużej mierze w koincydencji z realizacją polityki przyspieszenia przemysłowego, Włochy stopniowo wycofywały się z importu amerykańskiego uzbrojenia na rzecz zakupu licencji, m.in. w krajach EWG i podejmowania finalnej produkcji w kraju. Równocześnie następował szybki wzrost zaangażowania w te przedsięwzięcia kapitału publicznego. W 1963 r. produkcja sektora zbrojeniowego we Włoszech miała wartość około 400 mld lirów (3,5\% ogólnej produkcji przemysłu) i wykazywała wysoką dynamikę wzrostową ${ }^{86}$.

Pod kontrolą państwa pozostawała również większość przemysłu stoczniowego. W 1959 r. największe włoskie stocznie, w tym w Wenecji, Genui, Anconie, Palermo,

\footnotetext{
82 ISTAT, Annuario Statistico 1964, op.cit., s. 220; ISTAT, Annuario statistico 1959, Roma 1959, s. 217.

83 ISTAT, Annuario Statistico 1964, op.cit., s. 210; ISTAT, Annuario Statistico 1959, op.cit., s. 195.

${ }^{84}$ G. Maione, op.cit., s. 5.

${ }^{85}$ D. Sassoon, op.cit., s. 44.

${ }^{86}$ F. Battistelli, Armi: nuovo modello di sviluppo? L'industria militare in Italia, Einaudi Editore, Torino 1980, s. 128.
} 
La Spezi i w Castellamare di Stabia, zarządzane wcześniej bezpośrednio przez IRI, zostały podporządkowane kapitałowo powołanemu specjalnie w tym celu subholdingowi Instytutu pn. Finacantieri SpA (Cantieri Navali Italiani). Mimo korzystania $\mathrm{z}$ dotacji budżetowych oraz $\mathrm{z}$ ułatwień eksportowych $\mathrm{w}$ formie zwrotu podatku obrotowego branża przeżywała zastój i notowała pogłębiające się zadłużenie. Jedną z przyczyn było utrzymywanie, m.in. ze względu na silną pozycję związków zawodowych, nadmiernego $\mathrm{w}$ stosunku do realnych potrzeb kraju potencjału produkcyjnego, co znacznie obciążało koszty funkcjonowania stoczni i produkcji statków. Ograniczało to w konsekwencji konkurencyjność branży na rynkach międzynarodowych i uniemożliwiło wykorzystanie w pełni dobrej koniunktury na statki, jaka ukształtowała się po zablokowaniu Kanału Sueskiego w 1956r. W latach 1958-1963 produkcja włoskiego przemysłu stoczniowego wahała się rocznie od 330 tys. BRT do 500 tys. BRT, przy zdolnościach produkcyjnych przekraczających 650 tys. BRT. W 3/4 była ona realizowana w stoczniach należących do Finacantieri SpA ${ }^{87}$.

Jednym z czynników pozytywnie wpływających na dynamikę rozwojową całego przemysłu była dobra kondycja energetyki. W latach 1958-1963 zwiększyła ona produkcję o $45,9 \%^{88}$, znajdowała się w trendzie wzrostowym i zapewniała pełne pokrycie rosnącego zapotrzebowania na energię ze strony gospodarki. Z punktu widzenia struktury własności włoski rynek energii elektrycznej charakteryzował się znacznym rozdrobnieniem. Do listopada 1962 r. funkcjonowało na nim 1270 prywatnych, państwowych i komunalnych firm zajmujących się produkcją, sprzedażą lub dystrybucją. 61,6\% energii elektrycznej wytwarzał sektor prywatny skupiający w całym kraju około 1,5 tys. siłowni kontrolowanych w większości przez kilkanaście dużych spółek o charakterze regionalnym lub międzyregionalnym ${ }^{89}$.

W listopadzie 1962 r. włoski parlament głosami Chrześcijańskiej Demokracji i Włoskiej Partii Socjalistycznej przyjął ustawę o nacjonalizacji energetyki. Zgodnie z jej zapisami praktycznie cały system energetyczny, od elektrowni do firm zajmujących się dystrybucją, znalazł się w gestii nowo utworzonej, mającej charakter monopolu Narodowej Agencji Energii Elektrycznej (Ente Nazionale per l'Energia Elettrica, ENEL). Dotychczasowi właściciele znacjonalizowanych przedsiębiorstw otrzymali pełne, według wartości rynkowej, rekompensaty w postaci wyemitowanych w tym celu wieloletnich obligacji skarbowych ${ }^{90}$. Nacjonalizacja energetyki była kulminacyjnym etapem rozwoju sektora państwowego we Włoszech i najbardziej

\footnotetext{
87 ISTAT, Annuario statistico 1964, op.cit., s. 216.

88 Ibidem, s. 207.

89 R. Rosario, op.cit., s. 231.

90 E. Caruso, op.cit., s. 28.
} 
reprezentatywnym przykładem realizowanej przez władze włoskie polityki interwencjonizmu w tamtym okresie.

Ważnym aspektem nacjonalizacji energetyki był jej kontekst i skutki polityczne. Ustawa o jej przeprowadzeniu była ewidentnie efektem partyjnego kontraktu między chadecją a socjalistami i miała utorować drogę do współpracy parlamentarnej obu partii i utworzenia przez nie w przyszłości koalicji rządowej. Ostatecznie do porozumienia w tym zakresie doszło już w grudniu 1963 r. Poza wymiarem politycznym miało ono istotne znaczenie również w sferze polityki gospodarczej, bowiem obie partie prezentowały zbieżne, choć wynikające z odmiennych przesłanek ideologicznych, poglądy na rolę państwa w gospodarce. W konsekwencji nowy, centrolewicowy układ koalicyjny z udziałem partii socjalistycznej na wiele lat spetryfikował pozycję sektora państwowego w gospodarce włoskiej i de facto usankcjonował politycznie istnienie mieszanego, prywatno-państwowego systemu gospodarki rynkowej we Włoszech.

Mimo głębokiego kryzysu, jaki dotknął gospodarkę włoską w latach 70., sektor państwowy, chociaż stał się z czasem niewydolny oraz nadmiernie zadłużony z powodu upolitycznienia menedżmentu i przedkładania przez niego celów politycznych nad rachunek ekonomiczny, przetrwał w prawie niezmienionej formie aż do połowy lat 90., kiedy w wyniku głębokich zmian na scenie partyjnej we Włoszech zapadła polityczna decyzja o likwidacji IRI i prywatyzacji wszystkich jego aktywów. Formalnie nastąpiło to w $2000 \mathrm{r}$.

\section{Podsumowanie}

Działalność sektora państwowego we Włoszech w okresie odbudowy kraju ze zniszczeń wojennych i następnie w latach boomu gospodarczego należy ocenić generalnie pozytywnie:

- bezpośrednio po wojnie jego aktywność została ukierunkowana na odbudowę podstawowych działów przemysłu, konwersję produkcji wojennej na pokojową, stanowiła też uzupełnienie działalności gospodarczej sektora prywatnego i koncentrowała się na dziedzinach o wysokich nakładach inwestycyjnych i niskiej rentowności, którymi kapitał prywatny nie był zainteresowany;

- w kolejnych latach przedsiębiorstwa kontrolowane przez państwo, urzeczywistniając strategiczne cele polityki ekonomicznej władz, przejęły rolę najważniejszego inwestora w kluczowych dla kraju projektach i stały się ważnym czynnikiem stymulującym rozwój przemysłu, pożądane zmiany strukturalne w gospodarce oraz wzrost zatrudnienia; 
- państwowe koncerny ENI i IRI wniosły istotny wkład w industrializację i rozwój gospodarczy Mezzogiorno, chociaż nie osiągnęły wyznaczonych celów ani pod względem poziomu inwestycji i produkcji przemysłowej, ani w zakresie tworzenia nowych miejsc pracy; bez względu jednak na ocenę ich skuteczności w tym zakresie należy podkreślić, że jakikolwiek rozwój Południa nie byłby możliwy bez liczącego się zaangażowania kapitałowego państwa, zwłaszcza w dziedzinach charakteryzujących się największym ryzykiem inwestycyjnym.

Najważniejszymi negatywnymi aspektami działalności sektora państwowego była z jednej strony jego monopolistyczna pozycja w niektórych dziedzinach przemysłu ograniczająca możliwości rozwojowe prywatnej konkurencji, z drugiej - jego systemowe podporządkowanie polityce, czego efektem było m.in. szerzenie się takich patologicznych zjawisk, jak upolitycznienie menedżmentu prowadzące do niegospodarności i nieprofesjonalnego zarządzania firmami oraz klientelizm wyrażający się w nielegalnym finansowaniu partii, korumpowaniu polityków i urzędników, traktowaniu firm państwowych jako miejsca wygodnych, dobrze płatnych synekur.

\section{Literatura}

Amatori F., Colli A., Impresa e industria in Italia dall'Unità a oggi, Marsilio, Venezia 2001.

Balcet G., Leconomia italiana, evoluzione, problemi e paradossi, Feltrinelli, Roma 1997.

Barca F., Storia del capitalismo Italiano, Donzelli Editore, Roma 1997.

Battistelli F., Armi: nuovo modello di sviluppo? L'industria militare in Italia, Einaudi Editore, Torino 1980.

Bianchi P., La rincorsa frenata. L'industria italiana dall'unita nazionale all'unificazione europea, Il Mulino, Bologna 2002.

Biscaini A., Gnes P., Roselli A., Origini e sviluppo del Consorzio per Sovvenzioni su Valori Industriali durante il Governatorato Stringher, Bancaria, Roma 1987.

Cafiero S., Storia dell'intervento straordinario nel Mezzogiorno (1950-1993), Piero Lacaita Editore, Manduria 2000.

Candeloro G., Storia dell'Italia moderna. Il fascismo e le sue guerre, Feltrinelli Editore, Milano 1981.

Cardini A., Il miracolo economico italiano, Il Mulino, Bologna 2006.

Caruso E., Storia ed economia italiane negli anni' 50 e avvio anni ' 60 , www.impresaoggi. com/articoli/

Crainz G., Storia del miracolo italiano. Culture, identitá, trasformazioni fra anni cinquanta e sessanta, Donzelli, Roma 1996. 
Czynniki wzrostu wydajności i dochodu we Włoszech w latach 1951-63, GUS, Warszawa 1970. Franzinelli M., Magnani M., Beneduce, il finanziere di Mussolini, Mondadori, Milano 2009. Graziani A., Leconomia italiana 1945-1970, Il Mulino, Bologna 1972.

Kogan N., A Political History of Italy. The postwar years, Praeger, New York 1983.

Lefebvre H., Lo Stato, 3. Il modo di produzione statuale, Dedalo libri, Bari 1977.

Le Plan Vanoni et léconomie italienne, „La documentation française” nr 2040, Presidénce de Conseil, Paris 1955.

Maione G., Spesa pubblica o consumi privati?, „Italia Contemporanea” 2003, nr 231.

Misiani S., Lo schema Vanoni e il nuovo meridionalismo, w: Rivista, Scuola Superiore delleconomia e delle finanze, Centro Ricerche Documentazione Economica e Finanziaria (CRDEF), Roma 2004.

Możejko E., Włochy a integracja zachodnioeuropejska, PISM, Warszawa 1972.

Piotrowska-Hochfeld K., Zagadnienia wzrostu gospodarczego Włoch, PWE, Warszawa 1964.

Podbielski G., Italy: Development and Crisis in the Post-War Economy, University Press, Oxford 1974.

Ricciardi F., Una modernizzazione mancata? L'IRI e i "piani economici” dal dopoguerra al „miracolo economico", w: Workshop nazionale dottorandi in storia contemporanea, Università degli Studi di Napoli, Napoli 2006.

Rosario R., Breve storia della grande industria in Italia, Mondadori, Milano 1988.

Różycki S., Kierunki rozwoju gospodarki włoskiej po II wojnie światowej, Wydawnictwo CJNTiE, Warszawa 1966.

Ruffolo G., Il piano Vanoni, Il Mulino, Bologna 1955.

Sassoon D., Contemporary Italy. Politics, economy and society since 1945, Longman, London 1986.

Stringher B., Memorie riguardanti la circolazione e il mercato monetario, Banca d'Italia, Roma 1925.

ISTAT, Statistiche storiche dell'Italia, Roma 1976.

Trznadel W., Przestrzenne dysproporcje gospodarczo-społeczne we Włoszech XIX i XX wieku i drogi ich przezwyciężania, Wydawnictwo UWr, Wrocław 1988.

Vanoni E., La politica economica degli anni degasperiani. Scritti e discorsi politici ed economici, Le Monnier, Firenze 1977.

Vinci S., Il ruolo delle esportazioni nello sviluppo economico italiano del periodo 1951-1962, w: Lo sviluppo di un'economia aperta, Esi, Napoli 1969.

Wiskemann E., Italy since 1945, Macmillan-St. Martin's Press, London 1971.

Zamagni V., Nuovo meridionalismo e intervento straordinario. La Svimez dal 1946 al 1950, Il Mulino, Bologna 1988.

Zampaglione G., Italy, Ernest Benn Limited, London 1956. 


\section{State Sector During Postwar Development of Italy and During Economic Boom of 1950s and 1960s}

The state sector in the Italian economy dates to the $1930 \mathrm{~s}$. Although back than it was considered a temporary solution to help strategically important companies survive the Great Depression, it quickly grew. After the war the state sector was the prime enforcer of the governmental strategy of rapid industrialization. The general opinion on the activities of the state sector after the war is positive as it helped the economy grew and modernize. The downside laid particularly in close ties of the state sector to the political life of Italy and resulting scandals.

Keywords: Italy, public sector, IRI holding, Mezzogiorno, nationalisation, public investments

\section{Le rôle du secteur public dans le développement de l'Italie après la guerre et pendant le boom économique dans les années 50 et 60 du XXe siècle}

Le secteur public existe dans l'économie italienne depuis les années 30 du XXe siècle, initié par les autorités fascistes. Au cours de la crise économique mondiale, il était responsable pour le sauvetage de la faillite des entreprises et des banques économiques stratégique en Italie. Avant le déclenchement de la Seconde Guerre mondiale, l'Etat était déjà l'actionnaire majoritaire de plus de 100 usines, employant 201.000 employés et contrôlant $42 \%$ de la capitale italienne. Dans les années 50 le secteur public est devenu l'exécuteur principal de la stratégie gouvernementale d'industrialisation accélérée. Les activités du secteur de l'État dans la période analysée devraient être en général évaluées positivement.

Mots-clés: l'Italie, le secteur public, le holding IRI, mezzogiorno, la nationalisation, les investissements publics 


\section{Роль государственного сектора в послевоенном развитии Италии и в период экономического бума 1950-х и 1960-х гг.}

Государственный сектор в экономике Италии появился в 1930-е гг. Хотя сначала рассматривался как временное решение, принятое с целью помочь стратегически важным предприятиям преодолеть Великую депрессию, он быстро увеличивался. После войны государственный сектор исполнял главную роль в правительственной стратегии быстрой индустриализации. Роль государственного сектора после войны оценивается позитивно, так как он способствовал экономическому росту и модернизации. Отрицательно воспринимаются тесные связи между государственным сектором и политической жизнью Италии и сопутствующие им скандалы.

Ключевые слова: Италия, государственный сектор, IRI holding, Mezzogiorno, национализация, государственные инвестиции 